\title{
Chapter 23 \\ Biological Invasions and Ecological Restoration in South Africa
}

\author{
Patricia M. Holmes (D), Karen J. Esler (D), Mirijam Gaertner (D), \\ Sjirk Geerts (D), Stuart A. Hall D, Mlungele M. Nsikani $\mathbb{D}$, \\ David M. Richardson (D), and Sheunesu Ruwanza (ID)
}

\begin{abstract}
Invasive alien plant species can be a major cause of ecosystem degradation in South Africa, and ecosystem recovery may require restoration interventions beyond controlling the target alien species. Active restoration interventions are usually required if legacy effects result from the invasion. Legacy effects may induce regime shifts when thresholds to autogenic recovery are breached. In such cases, active restoration interventions will be required to manipulate the ecosystem along a trajectory to recovery. In some cases, alien control measures may be sufficient to restore a structurally and functionally representative ecosystem, provided that implementation occurs early in the invasion process and that the control methods do not hamper spontaneous regeneration. It is important that key stakeholders discuss and set realistic restoration goals at the project planning stage. Studies on the costs and benefits of ecological restoration indicate that when important services are improved, benefits outweigh the costs of alien clearing (assuming spontaneous regeneration of the native ecosystem). The costs of moderate, active restoration interventions are
\end{abstract}

P. M. Holmes $(\square) \cdot$ K. J. Esler $\cdot$ S. A. Hall

Centre for Invasion Biology, Department of Conservation Ecology and Entomology,

Stellenbosch University, Stellenbosch, South Africa

e-mail: holmes.patricia.m@gmail.com

M. Gaertner

Nürtingen-Geislingen University of Applied Sciences, Nürtingen, Germany

Centre for Invasion Biology, Department of Botany and Zoology, Stellenbosch University, Stellenbosch, South Africa

S. Geerts

Centre for Invasion Biology, Department of Conservation and Marine Sciences, Cape Peninsula University of Technology, Cape Town, South Africa

M. M. Nsikani · D. M. Richardson

Centre for Invasion Biology, Department of Botany and Zoology, Stellenbosch University,

Stellenbosch, South Africa

S. Ruwanza

Centre for Invasion Biology, Department of Environmental Science, Rhodes University,

Makhanda, South Africa

B. W. van Wilgen et al. (eds.), Biological Invasions in South Africa, Invading

Nature - Springer Series in Invasion Ecology 14,

https://doi.org/10.1007/978-3-030-32394-3_23 
economically viable, whereas the costs of fully restoring ecosystem structure, functioning and composition in highly degraded ecosystems are rarely deemed economically justifiable. Valuations of specific biodiversity components, such as threatened ecosystems and species, remain problematic to assess, and these components could be under-valued in such studies. South African researchers have made significant contributions to the theory and practice of restoration ecology globally and have produced local guidelines for ecological restoration. However, there has been limited uptake in implementing active restoration projects at larger scales. This apparent knowing-doing gap may have three causes: firstly, insufficient co-production by all stakeholders in planning restoration projects, including prioritisation and goal setting; secondly, shifting beyond clearing invasive alien species to restoring ecosystems; and thirdly, insufficient resources to implement active restoration projects at the necessary scale. To achieve Convention on Biological Diversity and the UN Sustainable Development Goals, interventions must shift from controlling invasive alien species alone to restoring native ecosystem structure and functioning.

\subsection{Introduction}

Many invasive alien plant species in South Africa cause substantial ecosystem changes, and are the focus of expensive management operations due to the perceived negative impacts on ecosystem services and biodiversity (Richardson and van Wilgen 2004; Gaertner et al. 2011; Le Maitre et al. 2011). Other main causes of ecosystem degradation include over-grazing by livestock (Carrick and Krüger 2007) and inappropriate fire regimes (Kraaij and van Wilgen 2014). These degrading forces sometimes act synergistically, since alien plants may exploit recruitment opportunities created by other drivers of vegetation change (Sher and Hyatt 1999). Invasive alien plants may also disrupt ecological processes, for example resulting in reduced palatable forage or altered fire regimes (Brooks et al. 2004). Such synergistic forces may further accelerate the loss of biodiversity and ecosystem services.

To reverse ecosystem degradation and control invasions, it is sometimes necessary to not only optimise control of the invasive alien species, but also to actively restore the altered ecosystem. According to the Society for Ecological Restoration, "Ecological restoration is the process of assisting the recovery of an ecosystem that has been degraded, damaged or destroyed" (Clewell et al. 2004). This is generally interpreted to mean implementing actions that will set an ecosystem on a trajectory towards recovery. Managers therefore require a deep understanding of the ecosystems they manage, including the extent and intensity of change that has occurred, the recovery potential of the native ecosystem and the interventions required to promote recovery. Key questions include: "Will the ecosystem self-repair following removal of the invasive alien species?"; "Which removal method best promotes natural ecosystem recovery?" and, if the ecosystem is degraded beyond a state where selfrepair is likely, "Is active restoration feasible and affordable?" 
Here we describe the contexts for ecological restoration following alien plant invasions, summarise theoretical and applied research, and outline South Africa's contributions to this field. Conceptual frameworks such as the "restorative continuum" (McDonald et al. 2016a, b) are useful in addressing ecological restoration requirements along a gradient of habitat change or degradation, and for visualising desired outcomes. Restorative interventions may be seen as a continuum from the bare minimum of reducing the causes of degradation in permanently modified habitats, to restoring to an appropriate natural reference ecosystem (McDonald et al. 2016a, b). When the potential for recovery (or progress to some desired state) is determined to have been compromised by invasive alien species, active restoration by manipulating the abiotic and biotic ecosystem components may be required to achieve goals. In contrast, removal of the invasion-mediated impact through appropriate control measures alone may be sufficient for ecosystems deemed to have good recovery potential. In practice, the latter generally refers to invaded ecosystems with intact native seed banks and/or surviving remnant native plant populations. Here we illustrate some outcomes of spontaneous regeneration and active restoration applications using South African case studies.

\subsection{Global and National Contexts}

\subsubsection{The Need for Ecological Restoration}

Restoration ecology is a relatively new science that gained prominence in the 1980s, and has since expanded in response to the human-induced, rapid rate of habitat transformation and degradation across the globe (Hobbs and Richardson 2011). Global land modification and degradation estimates range from 0.99-6 billion ha (up to $66 \%$ of global land surface) and the annual, economic costs arising from these impacts are estimated to be $\sim 10-17 \%$ of current global Gross Domestic Product (GDP) (Crossman et al. 2017). Various international instruments, to which South Africa is a signatory, seek to reverse this degradation, including the Bonn Challenge and Sustainable Development Goal 15 (Mohieldin and Caballero 2015) and the Convention on Biological Diversity Aichi Targets (2010). Within South Africa, the National Biodiversity Framework (Government Gazette No. 32474, 2009) summarises the actions required to conserve and restore the country's natural ecosystems.

\subsubsection{Restoration Ecology}

Empirical research in restoration ecology has promoted a deeper understanding of ecosystem structure and functioning (Pretorius et al. 2008; Gaertner et al. 2011; Zaloumis and Bond 2011). This has led to the development of conceptual models that link agents of change and ecosystem responses to potential restoration actions 
and outcomes (Carrick and Krüger 2007; Standish et al. 2007; Holl et al. 2011; Le Maitre et al. 2011; Davies et al. 2018). Threshold models have played a significant conceptual role. Initially they were applied in semi-arid rangelands to describe sudden shifts in ecosystem structure or functioning, where the degraded alternative ecosystem state was resistant to natural recovery (Milton and Siegfried 1994; Whisenant 1999). Subsequent work showed that sudden regime shifts (sometimes termed tipping points) also operate in many other types of ecosystems previously assumed to follow linear degradation or successional trajectories (Gaertner et al. 2012b; Richardson et al. 2007). Traditional restoration approaches in degraded lands may fail due to constraints such as local loss of native species, seed dispersal limitations, shifts in dominance, altered biogeochemical processes and altered feedbacks that entrench an undesirable stable state (Beisner et al. 2003; Norton 2009; Suding et al. 2004). Threshold models that incorporate alternative ecosystem states and feedbacks can be applied to assist in habitat management decision-making (Standish et al. 2007; Gaertner et al. 2012b; Suding and Hobbs 2009).

It is reasoned that restoring ecosystem structure (including functional group diversity) will simultaneously restore ecosystem functioning (Holmes and Richardson 1999). Mori et al. (2013) explored the links between biodiversity, ecosystem stability and functionality, and how degradation may affect these. They suggested that traditional measures such as species diversity do not adequately capture aspects that are pivotal for ecosystem resilience, which requires the recovery of guilds representing the range of functional responses required to drive key processes. Sudden shifts to alternative ecosystem states coincide with a rapid loss of functional diversity that results from an aggregated loss of response diversity. Mori et al. (2013) emphasise that perspectives incorporating functional effects and responses of biodiversity are essential for developing restoration management strategies. However, the recovery of functions may lag behind structure in some ecosystems such as riparian forests (Matzek et al. 2016). Furthermore, where abiotic thresholds have been crossed, such as under climate change, the situation is likely to be more challenging. Climate change might reduce the effect of some stressors whilst enhancing others, further complicating restoration efforts (Rohr et al. 2018, 2013).

Implementing ecological restoration is complex: managers need to assess the impacts of degradation on ecosystem functions and recovery potential as well as the likely impacts of different management interventions. Lack of consideration for all aspects involved in restoration has likely resulted in limited success of implementation (Kettenring and Adams 2011). In addition, global change impacts such as habitat loss, fragmentation, biological invasions, and climate change may influence restoration outcomes. In South Korea, an approach using flexible restoration targets was applied: this considered ecosystem functions and functional trait diversity, rather than historic precedents, to create model restoration projects and implement adaptive management (Temperton et al. 2014). Because there is a need to improve restoration outcomes, share information from different restoration projects, and acknowledge stakeholder contexts, James and Carrick (2016) advocated the use of quantitative systems models. These models link ecological processes, and potentially social processes, that influence the desired outcome. Data gathered from 
empirical studies can be tested against a quantitative systems model to iteratively improve restoration outcomes for a particular ecosystem.

A major complication for restoration is the incorporation of larger-scale ecological processes, such as hydrological regimes and climatic factors that may limit the feasibility or trajectory of a desired outcome (Richardson et al. 2007). This may entail relaxing restoration goals based on historically informed reference systems (Prins et al. 2004; Aronson et al. 2017; Balaguer et al. 2014) to more flexible ones based on the new combination of environmental factors (Hobbs et al. 2009). This requires a detailed understanding of how local and regional processes influence population and community dynamics in the target ecosystem (Holmes and Richardson 1999; Suding and Leger 2012).

\subsubsection{Biological Invasions and Restoration Ecology}

Studies have shown that invasions of alien plants cause substantial changes to ecosystems by breaching biotic or abiotic thresholds to recovery (Suding and Hobbs 2009; Gaertner et al. 2012b). Biological invasions can also be the driver of ecosystem change during the restorative process (Norton 2009), resulting in altered ecosystem composition and structure. This implies that removal of the invaders alone may not lead to recovery, and indeed that such actions may divert successional processes in unwanted directions that may require additional interventions (active restoration measures) to fix. Despite the well-documented problem of impacts caused by invasive alien plants (Vilà et al. 2011; Downey and Richardson 2016; Le Maitre et al. 2011), a review of ecosystem restoration studies found that only $8 \%$ had control of invasive alien species as their main objective (Gaertner et al. 2012a). In those $8 \%$ of studies, the prevalent cause for degradation was invasive alien species outcompeting and replacing native species, indicating that a biotic threshold to recovery had been crossed. Measures other than invasive alien control were implemented in $65 \%$ of those cases (Gaertner et al. 2012a).

Invasive aliens with potential for causing regime shifts should be prioritised for control, as these species can modify ecosystems to their own benefit and suppress native species through reinforcing feedback processes that present barriers to recovery (Gaertner et al. 2014). Feedbacks likely to result in regime shifts were related to processes associated with seed banks, fire and nutrient cycling (Gaertner et al. 2014). A recent review of soil legacy effects resulting from invasion by alien $\mathrm{N}_{2}$-fixing woody species identified several potential barriers to restoration following alien control (Nsikani et al. 2018). Biotic barriers included altered soil microbial communities, depleted native seed banks, secondary invasions of alien species, and weedy native species dominance. Altered soil properties, especially those involving $\mathrm{N}, \mathrm{C}$ and moisture, potentially thwart restoration in some ecosystems.

These barriers to restoration point to the need for active restoration to facilitate recovery. There are numerous potential interventions that can be applied on their own or in combination. However, for most ecosystems, more experimental work is 
required to test optimal treatment combinations. Examples of where this has been explored for the Fynbos Biome in South Africa include: (1) highly degraded, alien grass-dominated renosterveld shrubland, where a combination of fire or tillage and herbicide treatments followed by active restoration sowing met the desired outcomes (Waller et al. 2016); (2) mountain fynbos densely invaded by woody alien pines and wattles, where alien clearance resulted in good spontaneous regeneration from the soil-stored seed bank, but ecosystem structure was improved by sowing the seeds of additional species that had been displaced (Holmes 2001b); and (3) lowland fynbos that was densely invaded by alien wattles, where native seed banks were too depleted to support spontaneous regeneration, necessitating active sowing to restore vegetation structure after alien clearance (Hall 2018). These examples illustrate that even within the same biome, different approaches may be required, depending on the ecosystem affected, the invasive alien species and the type of degradation that has occurred at a site. However, resource-intensive, active restoration interventions, such as comprehensive species sowing, may only be justifiable for priority threatened ecosystems.

Richardson et al. (2007) reviewed studies of riparian vegetation restoration following alien plant invasions. They recommended that a framework for restoration should consider biogeographical processes at different spatial scales, and specific relationships between invasive alien plants, resilience and ecosystem functioning. For example, large-scale, human-mediated changes, such as impoundments, can alter downstream river geomorphology in favour of the invasive alien species and limit the outcomes of reach-scale restoration (Rouwntree 1991).

\subsubsection{Biological Invasions and Restoration Ecology in South Africa}

South Africa has been a prominent contributor to global invasion science since the 1980s (Macdonald et al. 1986; Richardson et al. 1997; Wilson et al. 2014), and the management of invasions has been a strong component of this research (van Wilgen 2018). Given the importance of catchment areas for providing water and conserving the country's rich biodiversity, coupled with the escalating threat posed by alien plant invasions in these areas, it is not surprising that ecological restoration has developed here as a complementary research stream to invasion biology (van Wilgen et al. 2016). The past two decades have seen a closer integration of the two disciplines, in both theoretical and empirical research aspects (Gaertner et al. 2012a). Restoration ecology studies have enabled us to test our understanding of ecosystem structure and functioning (Gaertner et al. 2011; Holmes and Richardson 1999), and to explore ways of improving restoration when managing alien-invaded ecosystems (Holmes 2001b; Waller et al. 2016).

Disproportionate research attention has focussed on the Fynbos Biome, which covers only $4 \%$ of South Africa. Early analyses showed that this Mediterraneanclimate biome was more severely invaded than other biomes, though not necessarily 
more susceptible to alien plant invasions (Macdonald 1984). An unusual feature of plant invasions in the fynbos is the prominence of alien trees and shrubs originating from other Mediterranean-climate regions of the globe (Richardson et al. 1997). Owing to the negative impacts of these alien species on ecosystem services, particularly water supply, and locally endemic and highly threatened biodiversity (the Fynbos Biome has $38 \%$ of the country's critically endangered ecosystems and $67 \%$ of threatened plant taxa; Raimondo et al. 2009), research to document these impacts was intensified (Richardson and van Wilgen 2004). A motivation to the national government by stakeholders in the Fynbos Biome for a large-scale intervention for alien control resulted in the "Working for Water" programme being initiated in 1995 (Marais and Wannenburgh 2008). This programme stimulated continued research into the impacts of invasion and invasive alien control methods, including restoration.

A significant discovery that revolutionised restoration in fynbos and other fireprone ecosystems is that chemicals in smoke stimulate germination in many taxa (Brown 1993). This cue promotes seedling recruitment in the immediate post-fire environment and can be used as a pre-treatment for seeds, in combination with heat shock for some taxa, to optimise native species establishment in restoration projects (Hall et al. 2017).

\subsection{Restoration After Biological Invasion}

\subsubsection{The Restorative Continuum}

An overarching goal of managing biological invasions is to halt or slow the spread of the invaders, which entails intercepting invasion pathways and managing invaded landscapes in an integrated way. For ecological restoration, however, the overarching goal is to optimise ecosystem recovery, i.e. structure and functioning, using spontaneous regeneration or active interventions as the situation requires (McDonald et al. 2016a, b; Aronson et al. 2017). These two goals can be synergistic, and optimal restoration outcomes are most likely to result from good planning and implementation that integrates the research findings from both invasion biology and restoration ecology.

If one considers the restorative continuum in relation to biological invasions, the costs of ecosystem repair increase as a function of the extent, duration and intensity of environmental damage caused by the invasive alien (Milton et al. 2003; Holmes et al. 2007). It is therefore important to act early in the invasion process, before biotic and abiotic thresholds have been crossed, as costs increase according to the number of interventions required to restore a resilient, functional ecosystem (Aronson et al. 2007). In the case of highly modified habitats, such as road embankments or quarries, removal of invasive alien species may be the only action needed to attain the optimal goal, i.e. to halt spread of the invader. Active restoration interventions such as native species re-introduction may not be warranted in such situations, 
owing to the high costs of procuring native propagules and/or the high likelihood of failed introductions owing to the highly modified biophysical conditions. However, if re-invasion is likely, there may be a case for revegetating modified areas with alternative, non-invasive species to pre-empt re-invasion. In highly modified sites, there may be examples where replacing the invasive alien with resilient native species could improve landscape functions, such as reconnecting fragmented areas of natural habitat. In less modified habitats where there is potential for autogenic recovery through spontaneous regeneration, alien control may be sufficient to re-instate a structurally and functionally representative ecosystem (Gaertner et al. 2011; Mostert et al. 2017). However, where key structural or functional guilds have been severely depleted, active restoration through native propagule re-introduction, and possibly other actions, may be required. Where the conservation status of an ecosystem is a high priority, active restoration may be justified to further improve community composition and restore viable populations of threatened species (Morgan 1999; Hitchcock et al. 2012). Ensuring that key ecosystem processes (e.g. fire and herbivory) are initiated and maintained are important for optimising recovery.

\subsubsection{Ecological Restoration Following Invasion: A Conceptual Framework}

Gaertner et al. (2012b) modified models for dryland ecosystem degradation and repair (Milton and Siegfried 1994; Whisenant 1999, 2002) to develop a conceptual framework for restoring ecosystems degraded by invasive alien plants. They outlined a three-threshold conceptual model (Fig. 23.1) and linked the concept of ecosystem resilience to degradation thresholds. Resilience in this context is the ability of an ecosystem to spontaneously regenerate following invasive alien plant controls. A threshold is the point beyond which the ecosystem cannot self-repair following alien control alone, has lost resilience, and has formed an alternative state. The first threshold along the invasion-degradation gradient is usually biotic, and is indicative of a shift in structural biotic interactions within the invaded community for which recovery requires manipulation of vegetation components. In ecosystems where the biotic threshold has been reached, restoration interventions should include the re-introduction of missing plant guilds in addition to invasive alien vegetation control.

The second transitional threshold is reached after a longer duration of invasion and is harder to reverse. It is controlled by abiotic limitations that result from amplified biotic interactions and restoration requires manipulation of the physical environment in addition to the biotic components. Where alien species incur legacy effects such as $\mathrm{N}$ enrichment (Nsikani et al. 2018), this may be a barrier to restoration and may require the physical removal of nutrient-rich biomass (Marchante et al. 2009), the manipulation of soil nutrients (Zink and Allen 1998; Török et al. 2000), or the use of fire to volatilise excess nutrients. In many cases, biotic and abiotic 
High degradation

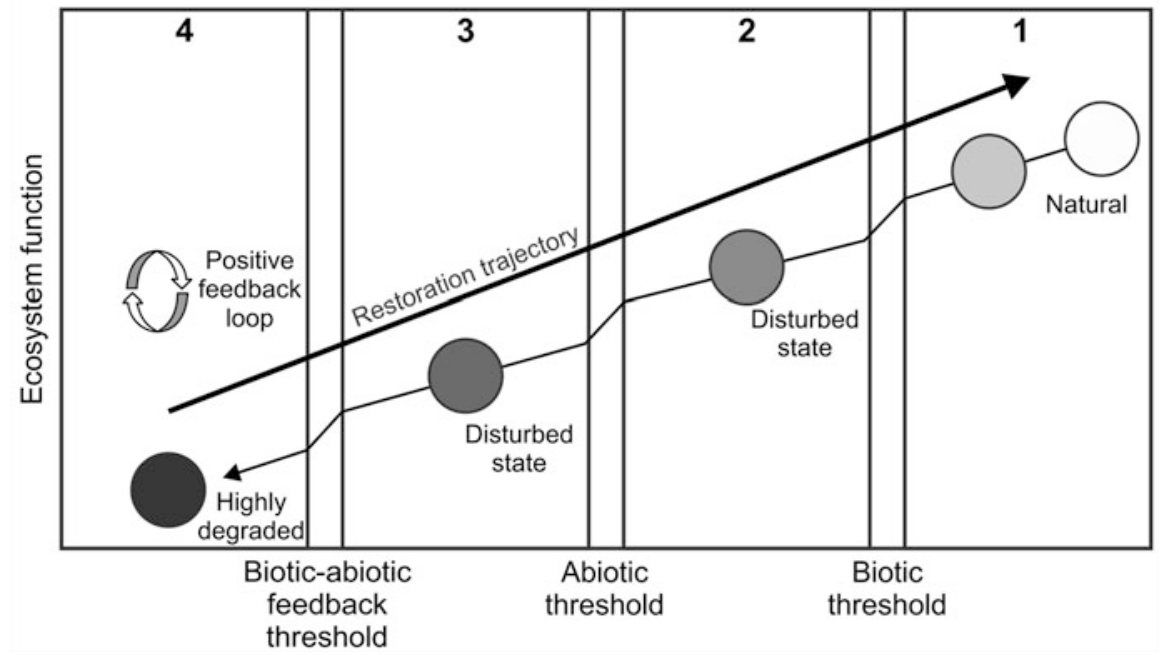

Fig. 23.1 Conceptual stepwise degradation model indicating three thresholds along an invasion intensity gradient (after Gaertner et al. 2012a; Stanturf et al. 2014). Thresholds indicate break points between alternative ecosystem states that require specific restoration interventions to ensure ecosystem recovery: (1) natural ecosystem state where no threshold is reached (e.g. altered species composition but above-ground vegetation and/or seed banks intact); (2) alternative ecosystem state where biotic threshold is reached (e.g. altered species composition and structure, depleted seed banks); (3) alternative ecosystem state where abiotic and biotic thresholds are reached (e.g. altered water and nutrient availability); and (4) alternative ecosystem state where positive feedback loops entrench a highly degraded state (e.g. changed fire regime favours persistence of the invader and prevents re-establishment of native species)

threshold effects are closely linked and may occur simultaneously. At this point management recommendations for ecological restoration are complex and experiments in the field may be required to determine the optimal combination of restoration treatments required, the interaction effects among treatments (e.g. use of fire, herbicides, seeding and planting) and the optimal timing of these interventions (Waller et al. 2016). However, if the duration of invasion can be reduced by timely alien control, changes to ecological functions may be avoided and an abiotic threshold may not have been reached. This research is useful to guide local ecological restoration projects while advancing our ecological knowledge of the system being restored, including seed ecology, community dynamics, ecosystem-level changes and mutualisms, to name a few.

Control of plant invaders can create bare ground that can be re-invaded by the same alien species or by secondary plant invader species (Pearson et al. 2016). This effect can be amplified if both biotic and abiotic thresholds have been crossed, as the altered conditions may favour competitive, weedy species. An example of secondary invasion is the colonisation by weedy herbaceous species in areas cleared of N-fixing alien acacia trees (Richardson et al. 2000; Yelenik et al. 2004; Nsikani et al. 2017). 
Minimising re-invasion is an important restoration objective and may require manipulation of both the biotic and abiotic components of the degraded ecosystem. Actively re-establishing canopy cover of native species may also be required to suppress the weedy, light-requiring secondary invader species (Falk et al. 2013; Herron et al. 2013).

The third degradation threshold may be reached at a later stage of invasion and results from positive biotic-abiotic feedback loops, whereby the persisting alien invader entrenches the changes in ecological processes that in turn further promote the invader above native species (Gaertner et al. 2014; Vilà et al. 2011; Suding et al. 2004). Examples of where the invader disproportionately benefits, ultimately resulting in the third degradation threshold being reached and preventing the re-establishment of native species, includes altered nutrient-cycling patterns (Gaertner et al. 2012b) and altered fire regimes resulting from increased biomass and/or changed fuel distribution (D'Antonio and Vitousek 1992). Once the third degradation threshold is reached, ecological restoration may be very difficult and expensive; in such cases less ambitious goals, such as rehabilitation, may be more realistic.

\subsection{Best Practice: Restoration Planning}

Whatever the context for an ecological restoration project, good planning and stakeholder involvement are essential if restoration goals are to be achieved. Following the four principles outlined by Suding et al. (2015), planned restoration projects strive to increase ecological integrity, i.e. either through alien control and spontaneous regeneration, or through additional interventions in tandem with alien control. Secondly, restoration is best planned for long-term sustainability. For example, practitioners can ensure that sufficient resources are available for followup alien control, monitoring and native propagule re-introduction if required, before embarking on initial control of the alien. The altered state of the ecosystem must be thoroughly assessed to ascertain whether restoration is likely to result in a sustainable, positive change. This would also assist in assessing priorities and setting realistic goals (D'Antonio and Meyerson 2002). Thirdly, most projects have goals based on a historically-informed reference ecosystem (Aronson et al. 2017). Nevertheless, it is also recommended to consider the future, and whether landscape-scale or global changes and external factors such as public perception could thwart desired restoration goals. Fourthly, restoration interventions should benefit and engage society.

Restoration planning should involve invasion and restoration ecologists, practitioners and other stakeholders who jointly develop restoration goals that are ecologically and economically feasible (Gaertner et al. 2012a). A participatory scenario approach for planning, implementing and monitoring restoration is one such inclusive approach (Metzger et al. 2017). At this stage, research questions may be addressed to fill knowledge gaps and data collected to better inform restoration 
best practice. Once the restoration project has been implemented, monitoring of outcomes should iteratively feed back into improving restoration actions, possibly using a quantitative systems modelling approach as advocated by James and Carrick (2016).

Stakeholders must be engaged early in planning to identify issues of concern that may compromise the ecological restoration goals (Metzger et al. 2017; Reyers et al. 2009; Urgenson et al. 2013). Ignoring such concerns could result in challenges to, or failure of, the project. For example, an alien species may provide an important resource for certain stakeholders and its removal could undermine their livelihoods (Kull et al. 2011). Engaging with such stakeholders may result in the project proceeding, provided that some alternative, non-invasive species resource is provided as part of the restoration project.

The Robust Offsetting restoration planning tool (RobOff) was applied to a large community reforestation project at a landfill site in Durban, to examine different restoration goals for the buffer zone (former sugar cane fields supporting invasive alien plants, with patches of native forest and grassland; Mugwedi et al. 2017). These goals included carbon storage, biodiversity and employment across a mosaic of habitats with varying levels of degradation and a limited budget (Mugwedi et al. 2018). The current restoration action was compared to three restoration intervention alternatives - spontaneous regeneration, carbon action and biodiversity action. RobOff indicated "biodiversity action" as the most beneficial in maximising the three goals, and that investing in biodiversity action would be preferable to the status quo (Mugwedi et al. 2018). Challenges included an increase in invasive alien plants, and alien control was included as a necessary restoration intervention (Mugwedi et al. 2017). Results from tools such as RobOff can help to inform stakeholder planning workshops of potential costs and benefits of different restoration interventions. In landscape-scale restoration projects, social and political processes may be more important to long-term success than ecological factors, therefore it is key to include multi-party stakeholders and specialists from the beginning (Aronson et al. 2017).

\subsubsection{Ecological Restoration Goals}

It has been argued that to become effective, adaptive and able to compete with other projects for resources, ecological restoration must become evidence-based (Ntshotsho et al. 2011). The three criteria required as evidence are baseline information, clearly defined goals, and monitoring. In a review of ten South African restoration programmes, Ntshotsho et al. (2011) found that of these three criteria only one, baseline information, was adequately addressed. Although both ecological and socioeconomic goals were set, these were found to be insufficiently clear. There was little monitoring of programme outcomes and monitoring of ecological indicators was inconsistent. To learn from early restoration attempts, it is important to define clear goals based on measurable parameters at the planning stage. These goals 
may be based on a historically-informed reference ecosystem (Prins et al. 2004), but must also be realistic - i.e. they must consider the intensity of past degradation and the ecological interventions necessary to promote recovery. Social and budgetary constraints should also be considered to ensure that realistic goals are set.

There are many different contexts and goals for ecological restoration of alieninvaded sites. In degraded ecosystems that retain intact soils, the first restoration action is usually to remove the invasive species, which may differ in structure and functioning from the dominant components of the native vegetation, and to re-instate ecosystem structure, either by stimulating the residual native seed bank or by re-introducing propagules of representative guilds. In so doing, it is anticipated that ecosystem functions and ecosystem services linked to these structural components will self-restore. However, it is important to collect baseline data on key functions and services and to monitor changes after the interventions, to test these assumptions and to modify the interventions as required. This approach is particularly important for invaded sites in areas identified as ecological infrastructure (e.g. water catchments) or high importance for ecosystem-based adaptation to climate change. In areas of high biodiversity importance, such as critically endangered ecosystems in global biodiversity hotspots, longer-term goals following the control of invasive alien plants may include the restoration of community composition and viable species populations.

\subsubsection{Prioritisation}

Resources are limited, so prioritisation is key to efficient restoration. An objective protocol that incorporates best-practice knowledge should be used, such as the Analytical Hierarchical Process (AHP), to select those restoration projects of the highest priority and/or likelihood of success (Mostert et al. 2018). AHP uses inputs from key stakeholders, who may participate in defining and scoring criteria for prioritisation, thus promoting a co-production approach during the planning process. An important principle in prioritising restoration projects is to first target the least degraded areas that have the highest potential for autogenic recovery (Holmes and Cowling 1997; Strydom et al. 2017).

\subsubsection{Costs and Benefits of Restoration Projects}

Intact ecosystems comprise the natural capital that in economic terms represents the stocks (i.e. component species) and the flows of ecosystem services upon which society depends. Degradation by invasive alien species disrupts these stocks and flows, and ecological restoration is required to reverse the impacts. However, what are the costs and benefits of doing so, and are the costs justified? Examples are not restricted to the improved ecosystem services delivered by the restored ecosystems, 
but include value-added industries related to alien biomass removal, such as firewood, charcoal and biomass to electricity industries (Stafford and Blignaut 2017). Managing and valuing ecosystem services remains a challenge in South Africa and globally, with native ecosystems typically undervalued, and is not limited to the field of restoration ecology. The accuracy of measuring restoration success is complicated because policy is still dictated by narrow, mainstream economic ideas (Costanza et al. 2017). Furthermore, information, databases and models related to ecosystem services in South Africa and elsewhere could be developed further, integrated and made available to stakeholders to ensure ecosystem services are optimised (Turner et al. 2016). One well-studied example is the negative impact of invasive alien trees on water supply and the benefits of restoring water catchments (Marais and Wannenburgh 2008).

Mountain fynbos ecosystems are important for the delivery of clean water to downstream agricultural and urban areas and for wild flower harvesting and ecotourism, among other services. Invasion by alien trees has severely disrupted these services (Holmes et al. 2007). Recovery potential is initially high in these ecosystems, owing to persistent soil-stored native seed banks, but this declines with the duration and density of invasion (Galloway et al. 2017; Holmes and Cowling 1997). For example, the benefit-cost ratio for total alien clearance (initial plus follow-ups) was 8:1 for medium-dense alien stands compared to $3: 1$ (at $4 \%$ discount rate) for long-term, closed alien stands (Holmes et al. 2007). Therefore, in an attempt to guide decisions on when restoration activities may be feasible, Crookes et al. (2013) coupled ecological restoration with system dynamics and portfolio mapping. They showed how restoration costs and derived benefits varied across sites, but that those projects in South Africa with the highest expectations of success and high payoffs were those associated with protection of water resources-justifying the focus on alien-clearing related restoration efforts in catchment areas.

Turpie et al. (2008) suggested that these valuable ecosystem services, such as water, should act as 'umbrella services' and that doing so would enhance broader conservation goals. In South Africa, payments for ecosystem services only started with the establishment of the Working for Water programme in 1995.

From an ecosystem services viewpoint, an increased investment in restoration activities often is warranted (Anderson et al. 2017). However, the effectiveness of these investments will differ depending on their costs and aims. For example, Currie et al. (2009) determined the cost-effectiveness of restoration by using the costs of invasive alien plant clearing, erosion control and revegetation as the input costs and water and tourism as the benefits. Importantly, they compared three different restoration options (comprehensive, moderate, basic) and three economic scenarios (optimistic, realistic, pessimistic). They found that comprehensive restoration was not worth the input costs, basic restoration was always economically viable, whilst for moderate restoration it depended on the economic scenario selected. Naturally, these results are highly dependent on the invasive alien species, the ecosystem type and potential benefits, highlighting the importance of conducting such studies in a variety of ecosystems. Gaertner et al. (2012c) showed that for flower harvesting, active fynbos restoration is financially feasible for flower harvesters compared to 
spontaneous regeneration, but mainly over the long term and in areas with low-density invasions.

Most restoration studies in South Africa are short term and are vegetationorientated (e.g. Galatowitsch and Richardson 2005; Blanchard and Holmes 2008; Ruwanza et al. 2013a; Kerr and Ruwanza 2016; Ndou and Ruwanza 2016). Recovery of other taxa is less well quantified, largely because of the untested assumption that the recovery of native vegetation will facilitate the recovery of other taxa and subsequently ecosystem services and functions (Kaiser-Bunbury et al. 2017). Recent South African studies do indicate spontaneous recovery of other taxa and a link to ecosystem services (Mgobozi et al. 2008; Colvin et al. 2009; Magoba and Samways 2010; Samways et al. 2011; Maoela et al. 2016; Modiba et al. 2017). Invasive alien plant species were found to negatively impact most on seed dispersers and nectar-feeding bird pollinators (Mangachena and Geerts 2017). Although a few bird species were still absent 10 years after vegetation recovery, bird species richness and abundance recovered, and all feeding guildsincluding pollinators and seed dispersers-were represented (JR Mangachena, unpublished data). However, this is likely to be context-dependant as invasive alien species may contribute additional food sources to the benefit of some pollinators (Geerts and Pauw 2009). Ecosystem processes such as pollination might not automatically be reinstated by restoring target plant species. But assessing these processes will provide an indication of the sustainability of restoration projects (Forup and Memmott 2005). A keystone species approach to restore ecosystem services might be a cost-effective way to achieve this (Traveset and Richardson 2006).

More studies are required to measure the extent to which the removal of invasive alien plant species will result in a restored ecosystem. In particular, clearing of invasive alien plant species can hamper native vegetation recovery through overuse of herbicides or the lack of follow-up clearing. This also adds additional cost to restoration, enhancing the uneconomical nature of some restoration interventions. Therefore, we argue that high quality alien control should be prioritised. Furthermore, invasive alien plant control is making very little progress, or none at all in many areas (e.g. McConnachie et al. 2012). We caution against claiming large potential ecosystem service benefits from the clearance of invasive alien plants (Stafford et al. 2017), since the desired goal of restoring ecosystem structure and function in support of these services might not materialise.

\subsection{Best Practice: Restoration Implementation}

\subsubsection{Legacy Effects, Ecosystem Functions and Drivers}

It is important to assess how different invasive alien species, and different levels of density and duration of invasion, affect restoration potential. For example, N-fixing alien Acacia species have higher negative impacts on the recovery potential of 
fynbos ecosystems than alien pines (Mostert et al. 2017). Acacias shade out native species quicker than do pines. Their legacy effects include large soil-stored seed banks, increased leaf litter and biomass accumulation, increased pressure from folivorous insects and phylopathogenic fungi and changes to soil chemistry (Maoela et al. 2016; Nsikani et al. 2017; Strydom et al. 2012; Yelenik et al. 2004), thus altering ecosystem functions such as nutrient-cycling. Their rapid growth to canopy closure halts native seed set, resulting in depletion of native seed banks (Holmes 2002; Mostert et al. 2017). By contrast, the legacy effects of pines are less pronounced, relating more to altered local hydrology through increased water use and increased biomass. However, long-duration, dense pine invasions cause the depletion of fynbos seed banks and reduced recovery potential (Galloway et al. 2017), and in grasslands the loss of the forb resprouter guild (Zaloumis and Bond 2011).

Where an alien species is adapted to fire in the invaded ecosystem, management interventions need to be carefully integrated to promote ecosystem recovery and avoid exacerbating the invasion through fire-stimulated germination and spread of the alien species. In the case of serotinous invaders such as Hakea and Pinus species, fire may be used after felling adult populations to kill their released seed, seedlings and saplings (van Wilgen et al. 1994; Table 23.1, Langeberg case study). The case study of Cape Flats Sand Fynbos restoration at Blaauwberg Nature Reserve highlights the legacy effects to be overcome following Acacia invasion for a critically endangered ecosystem in which restoring and conserving biodiversity is the ultimate goal (Table 23.1; Figs. 23.2 and 23.3).

In riparian ecosystems, invasions of alien Acacia species and River Red Gum, Eucalyptus camaldulensis, also induce legacy effects. Whereas nutrient enrichment was documented after Acacia invasions, concentrations of soil available nutrients did not change following Eucalyptus invasion along the Berg River, although soil $\mathrm{pH}$ and moisture decreased significantly, and soil water repellency increased (Tererai et al. 2015a; Ruwanza et al. 2013a, b). A decrease in soil nutrients was documented following clearance of Acacia species along the Palmiet River, Eastern Cape (Ndou and Ruwanza 2016). In the lowland Berg River case study (Table 23.1; Fig. 23.4), E. camaldulensis produced allelopathic chemicals that suppressed germination and growth of four native species (Ruwanza et al. 2015). The soil seed banks retained some potential to initiate recovery after alien control but contained a high proportion of alien herbaceous weedy species that caused secondary invasions post-control (Tererai et al. 2015b). By contrast, in mountain stream and foothill reaches, fynbos riparian ecosystems are relatively resilient to invasion and good spontaneous regeneration followed the removal of large alien trees (Blanchard and Holmes 2008). Although not all riparian species have soil-stored seeds, seed banks had potential to initiate recovery after alien control (Fourie 2008; Vosse et al. 2008), as was also found along the Sabie River in the Kruger National Park (Morris et al. 2008; Table 23.1; Fig. 23.5).

Most lowland rivers traverse highly modified landscapes, and suffer profound alterations to hydrological regimes and geomorphology, due to upstream impoundments and conversion of riparian zones to agriculture or dense stands of alien trees (Holmes et al. 2005). Such large-scale alterations to ecological processes limit the 


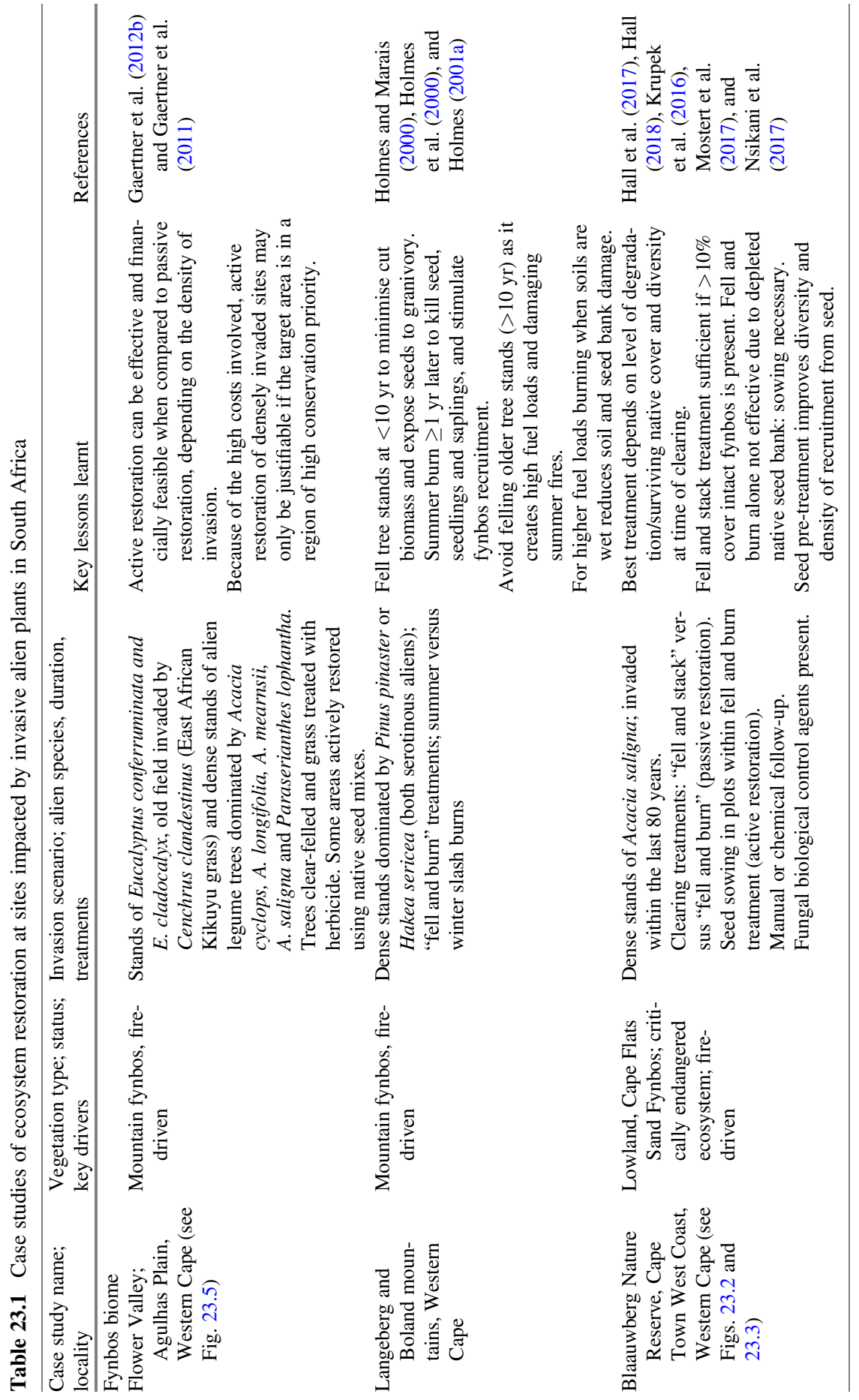



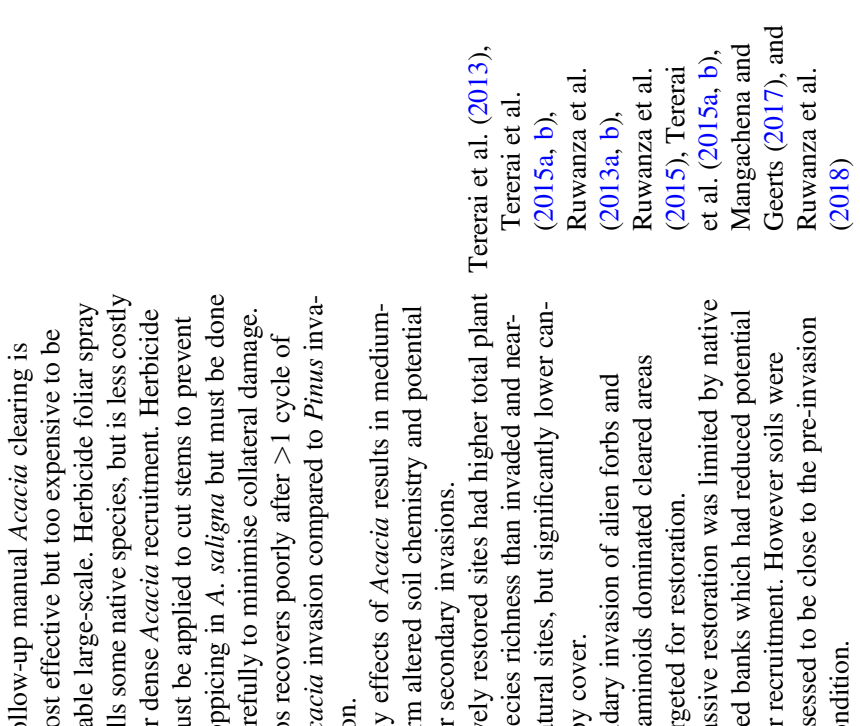

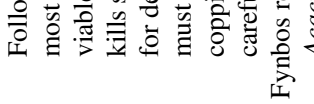
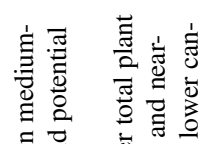

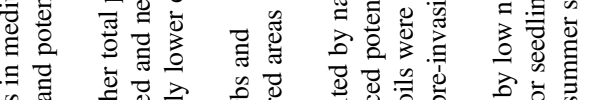

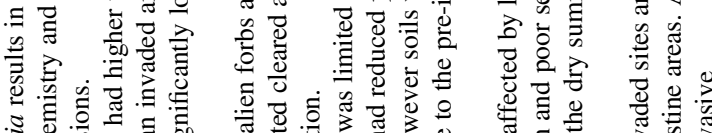

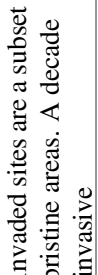

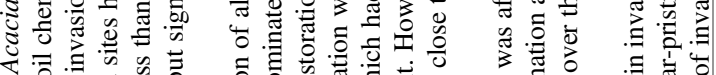

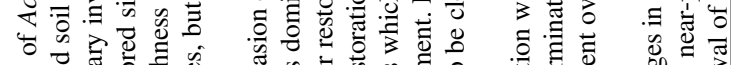

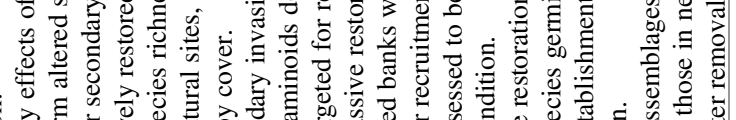

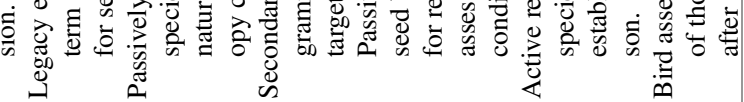
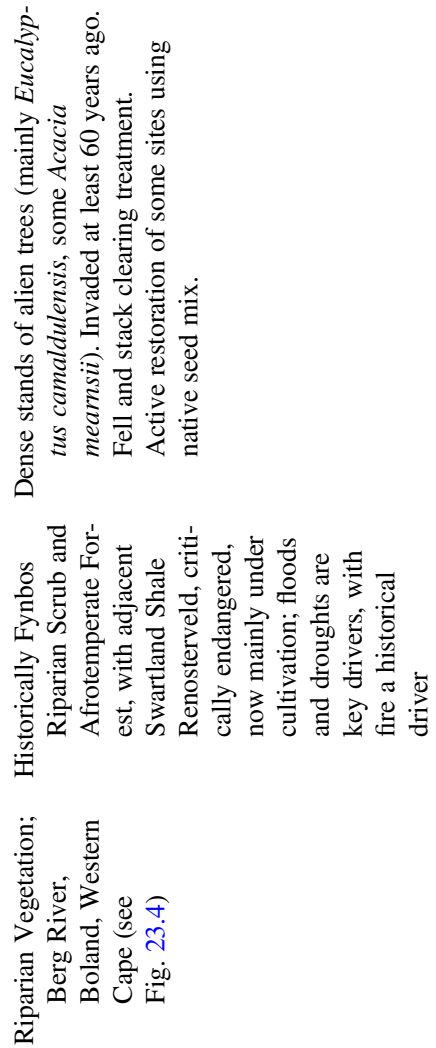


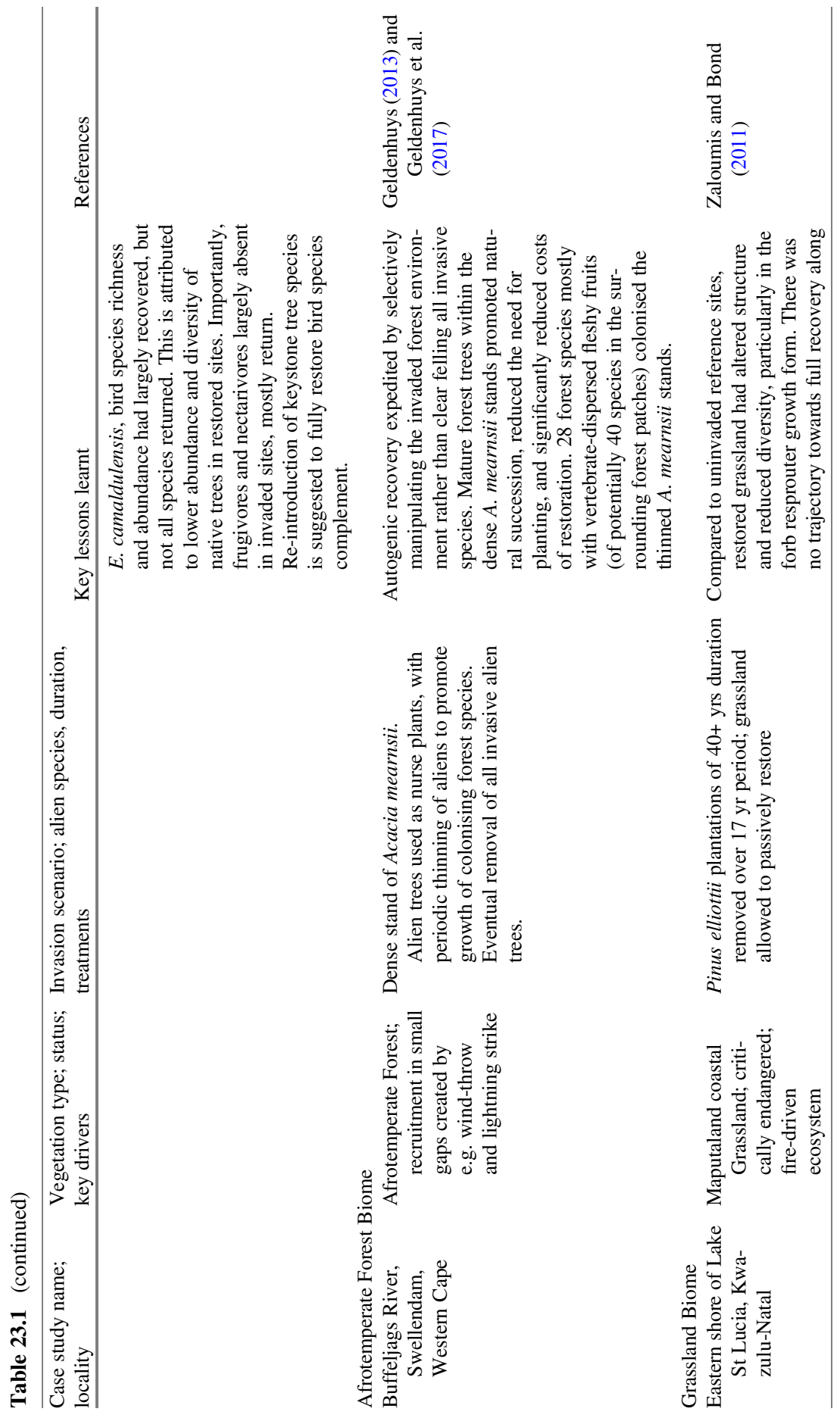











Fig. 23.2 A decision tree to guide ecological restoration in Acacia-invaded lowland fynbos shrubland (adapted from Hall 2018)

extent to which these ecosystems may be restored. For example, fires that historically swept across the lowland shrubland and riparian scrub communities no longer operate in an agricultural or urban matrix. Instead, remnants of riparian scrub have become colonised by vertebrate-dispersed species that are more typically present in fire-resistant sites (Meek et al. 2013). Such a community may be a more realistic target for long-term ecological restoration in lowland riparian ecosystems in a highly modified landscape. An additional challenge to restoration in lowland river systems is the altered flood regimes, mainly controlled by releases from upstream impoundments, that cause havoc with restoration plantings (J. van Biljon, pers. comm. August 2018). For many sites, restoration to anything resembling historical community structure and composition is unfeasible (Meek et al. 2013).

\subsubsection{Implementation: Spontaneous Regeneration}

Selecting the most appropriate alien control method to expedite spontaneous regeneration is important. A key consideration is the need to optimise recruitment by native soil-stored propagules and colonisation by wind or vertebrate-dispersed propagules that represent components of the historic ecosystem most suited to the local conditions. Although the most appropriate control method may be more expensive than standard methods, it may still be more cost-effective by eliminating 

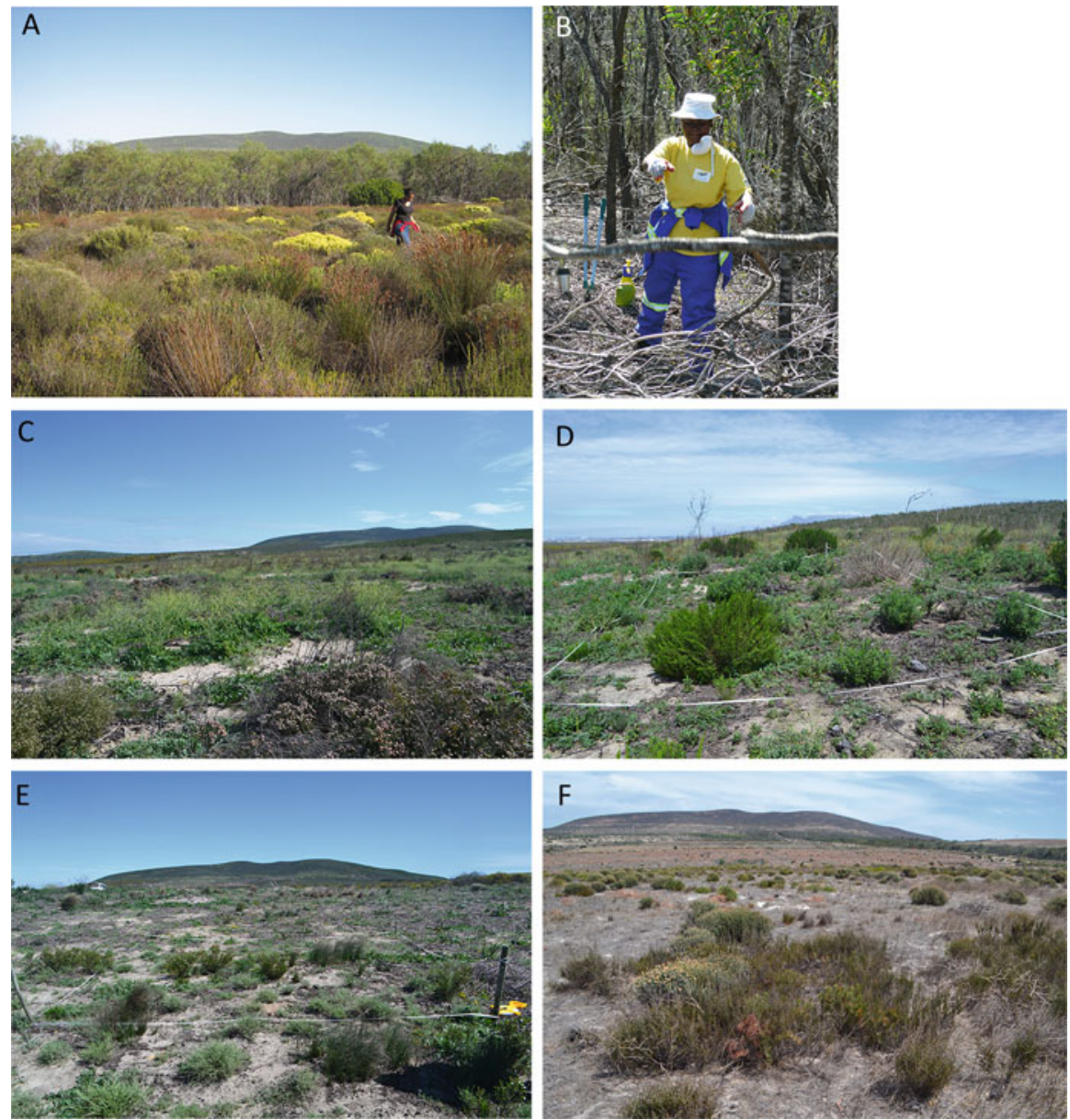

Fig. 23.3 Blaauwberg Nature Reserve Case Study. The photographs show: (a) A reference site for sand fynbos; (b) A worker clearing a dense stand of Acacia species; (c) Secondary invasion of a cleared site by herbaceous vegetation; (d) Recovery following clearing, with no fire applied (passive restoration); (e) Recovery by passive restoration following fire; and (f) Recovery following fire and sowing of seeds. Photographs courtesy of P.M. Holmes and S.A. Hall

the need for active restoration (Kimball et al. 2015). An important step is to assess which sites have moderate to good restoration potential. At such sites, control methods should attempt to minimise damage to native propagules, seedlings and adults, or attract dispersal agents, depending on the ecosystem (Table 23.1).

In grassland ecosystems invaded by Trifid Weed, Chromolaena odorata, integrated control using frequent fire after mechanical or chemical treatment was effective in controlling this species, as it is not fire-adapted. Furthermore, spontaneous regeneration by grassland species followed this treatment combination (Dew et al. 2017). 

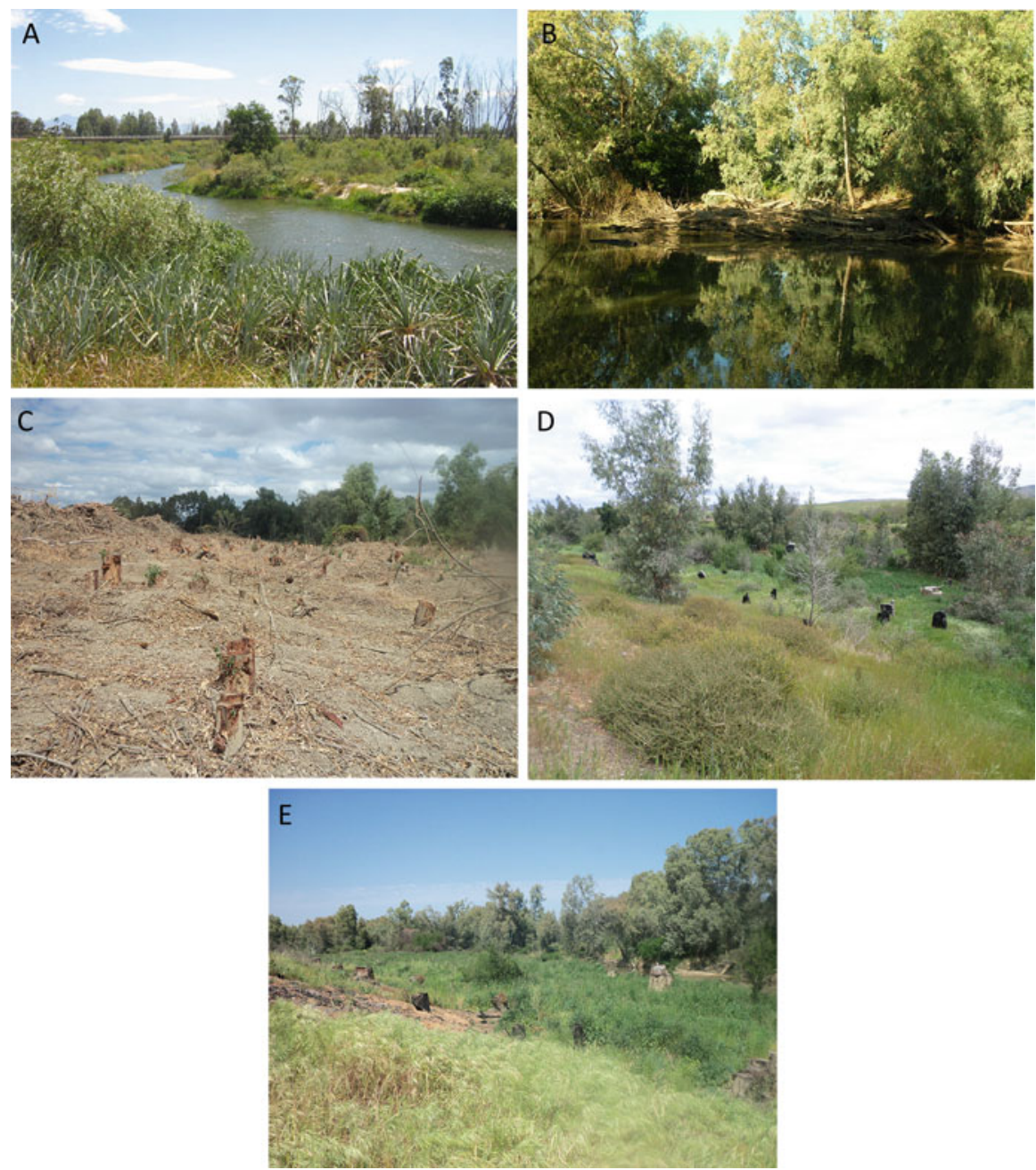

Fig. 23.4 Berg River Case Study. The photographs show: (a) A reference site for near-natural riparian vegetation; (b) Dense invasion of the riparian zone by Eucalyptus camaldulensis; (c) A site where the alien trees have been clear-felled following clearing; (d) Some recovery of native vegetation six years after clearing; and (e) Secondary invasion of the cleared site by grasses. Photographs courtesy of A. Rebelo and S. Ruwanza

In forest ecosystems densely invaded by alien trees, a phased approach to clearing the aliens better promoted conditions for in situ recruitment by vertebrate-dispersed forest species that germinate under a canopy and are shade-tolerant (Geldenhuys et al. 2017). The standard method of clear felling the aliens may leave large areas of bare ground without suitable frugivore perches or microclimatic conditions suited to dispersal, germination and establishment of native forest species. The Buffeljags River Forest case study (Table 23.1) illustrates the phased clearance approach, which 

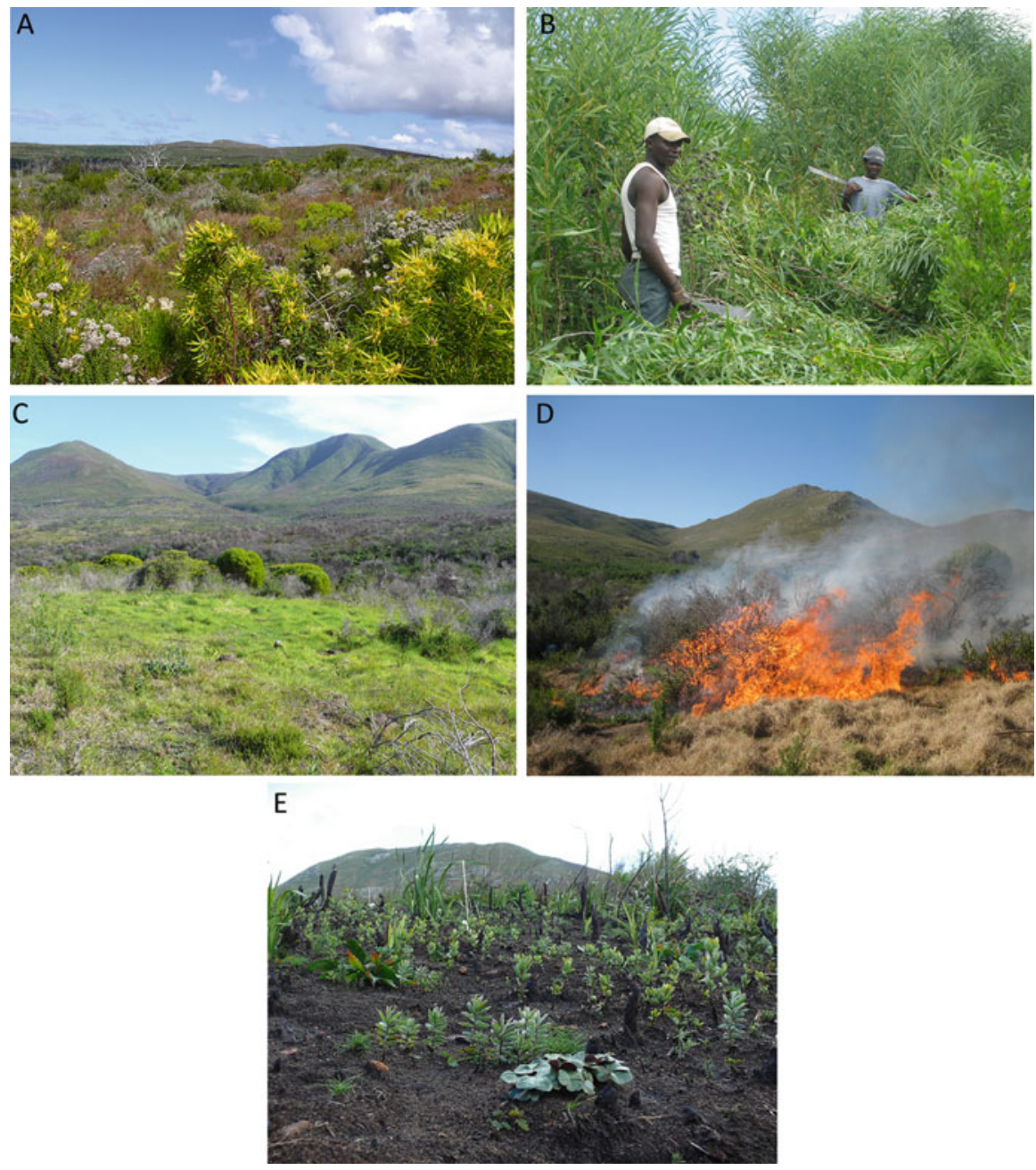

Fig. 23.5 Flower Valley Case Study. The photographs show: (a) A reference site for mountain fynbos; (b) A worker clearing a dense stand of Acacia species; (c) A dense invasion of the alien grass Cenchrus clandestinus; (d) A prescribed burn on the site following clearing; and (e) Seedling recruitment following sowing of seeds of native species. Photographs courtesy of M. Gaertner

was adopted as a four-stage alien thinning process to promote recovery in lowland riparian zones of the Berg River, where the restoration goal is thicket or forest (Ruwanza et al. 2013a, b).

For invasive alien species under effective biological control (Moran and Hoffmann 2012), integrated control is needed to best optimise the impacts of the 
biological control agents, as this will reduce future costs of restoration. For example in the case of the gall-forming rust fungus Uromycladium tepperianum on Port Jackson Willow, Acacia saligna, biological control substantially reduces the growth rate and canopy density of infected trees, allowing some fynbos species to persist in dense alien stands (Wood 2017). This slows the invasion process and maintains spontaneous regeneration potential in the invaded stands.

\subsubsection{Implementation: Active Restoration}

Where abiotic thresholds have been breached, interventions may be required to manipulate the abiotic environment before native species can be re-established. An example for nutrient-poor ecosystems includes reducing excess nutrients through removing or burning the litter layer and applying C-rich organic matter to immobilise nutrients (Zink and Allen 1998; Török et al. 2000; Gaertner et al. 2011). In riparian zones, steep banks and sediment accumulation resulting from stands of alien trees may first need to be re-contoured and flushed out, respectively, to create a more natural geomorphology before native wet and dry bank communities can be successfully re-established (Richardson et al. 2007). Exposure of bare soil and reduction in herbaceous cover following felling operations in riparian zones can result in secondary invasions (Beater et al. 2008; Table 23.1) which may be countered by planting native riparian species. If mutualistic microbial communities (e.g. specialist mycorrhizae) required for plant growth have been lost following long-term invasion or severe fires, soils or plants may first need to be inoculated to ensure successful re-introductions (Nsikani et al. 2018).

Native species may be restored from seed and propagated material. Seed is the preferred method for a number of reasons: it allows for more species and genetic diversity to be returned to the site, avoids the potential introduction of foreign soil, pests and parasites from nursery-grown stock, and potentially is more cost-effective, allowing larger areas to be restored. In grasslands, where the goal is to promote diversity, it is recommended to sow a propagule mix of grass species with low invasion potential (species with short stature, slow growth, low leaf mass and few tillers, Fynn et al. 2009). However, not all species are easily restored by seed. For example, fynbos obligate resprouter species produce few viable seeds (Marais et al. 2014) and in other species seeds are recalcitrant (Walters and Berjak 2013) thus cannot be collected and stored ahead of sowing. Some large-seeded species are nutritious and are highly parasitised or produce few viable seeds owing to granivory (PMH pers. obs.), while others are dependent on ants for dispersal and germination (Bond and Slingsby 1983). For threatened ecosystems there may be few intact remnants remaining as a source of suitable seeds for restoration, further limiting the available options. For some of the above examples, propagating new plants from cuttings and splits, or germinating from seed and first growing on before planting, may be more successful. In some cases, a combination of sowing and planting might be recommended to optimise the restoration outcomes. 
In semi-arid ecosystems, restoration success can be limited by poor establishment from actively seeded species (Madsen et al. 2016). Seed enhancement technologies, such as polymer seed coatings containing germination stimulants (e.g. smoke extract), have been shown to improve restoration success (Turner et al. 2006). Embedding the broadcast seed into the soil by raking and sowing at the optimal time of year greatly improved recruitment response (Turner et al. 2006). Hydroseeding is one mechanised method commonly used in roadside revegetation projects, but can be useful, albeit expensive, in areas accessible by vehicles (Martin et al. 2002). If the application slurry includes additives such as germination stimulants, mulch and organic soil binders, this can improve restoration efficiency compared to dry broadcasting methods.

For both seed and cuttings, it is important to collect material from the nearest remaining natural remnant, and also to match the habitat type for edaphic, hydrological and climatic variables, to improve the chances of establishment. Propagated material should be grown to develop strong rooting systems relative to shoot growth and preferably be grown in local soil and hardened off before planting to minimise planting shock and optimise establishment. Many plant communities develop in clumps rather than as regularly-spaced individuals, as positive interactions among individuals such as simple sheltering effects, can promote establishment. Where clumps or windbreaks may facilitate establishment, artificial wind breaks or alien slash should be used to create shelters. Furthermore, careful species selections that maximise trait diversity, or match niche requirements of the invasive alien species likely to re-invade, can enhance the likelihood of restoration success (Funk et al. 2008; Laughlin 2014).

Increasing surface roughness after fire, for example by using felled alien branches, can help to reduce surface erosion by raising the boundary layer and promoting the trapping of wind-dispersed native seeds from neighbouring intact remnants. Transferring seed-bearing branches of native pioneer shrubs to a burnt riparian zone resulted in good recruitment and augmented a sowing treatment (Pretorius et al. 2008). Where soil erosion may be a potential problem on steep slopes after alien control, both physical and biotic interventions should be considered. Alien logs or biomass may be pegged or stacked across the slopes to trap sediment and short-lived, commercially-available, non-invasive species sown to provide short-term soil surface stability. An example of the latter is the use of commercial wheat in nutrient-poor fynbos ecosystems, as it does not grow too vigorously or produce a viable seed bank under such conditions.

Granivores such as mice and gerbils may be prominent and voracious following alien clearance, therefore faunal control could be considered. For small mammals, the encouragement of raptors through erecting suitable perches on the restoration site may have a positive impact. Herbivores such as antelope preferentially browse or graze young vegetation, targeting the establishing plants, and the use of exclosures may be justified to ensure establishment.

Restoration of highly-degraded ecosystems to sustainable, fully functional natural ecosystems could take a long time, representing several generations or recruitment events (e.g. 45+ years for 3 generations in fire-driven fynbos). The reasons for this 
include that community re-assembly may not be even for all guilds and some may require repeated re-introductions, or new methods of propagation, should the initial approaches fail, as was found for restoring the diverse forb resprouter guild in coastal grasslands (Zaloumis and Bond 2011; Table 23.1). Variations in annual rainfall result in good and poor years for establishment of re-introduced species, and repeated re-introductions should be planned. This reality poses challenges for monitoring, and for the restoration practitioner who may be tasked with ambitious short-term restoration goals. Nevertheless, statistical and modelling tools allow for an assessment of early progress and whether the degraded ecosystems are developing along the desired trajectory (Hall 2018). Ecological goals must be as specific as possible and outcomes carefully monitored if effectiveness of the restoration interventions is to be fully assessed (Ntshotsho et al. 2011). Results of the monitoring should feed back into decision tree frameworks (Fig. 23.2) for the different ecosystems and indicate to managers whether treatments should be modified or remedial actions required.

\subsection{Conclusions}

Restoration ecology is a relatively young science, and numerous South African studies have improved the understanding of local ecosystem dynamics and ecological restoration principles in general. However, there is still a dearth of research on how non-plant taxa recover, as well as active restoration examples for biomes other than fynbos. The stimulus for local ecological restoration research has been the large negative impacts of invasive alien species on ecosystem structure and functioning, including the impacts on economically-important ecosystem services. Restoration is economically viable for specific ecosystem services such as water, which can serve as an 'umbrella service' to enhance other conservation goals. Other ecosystem services delivered via restoration, such as pollination, deserve more attention.

Ecological restoration is a long-term process that greatly exceeds the time-spans of most post-graduate research studies (see Hill et al. 2020, Chap. 19, for similar arguments). Early field results (2-3 years post-intervention) may not accurately reflect the restoration trajectory as measured in subsequent years (Ruwanza et al. 2018). More long-term studies are required that build on, and monitor, earlier shortterm field studies to further analyse the impacts of restoration interventions and to improve restoration guidelines. In addition, owing to the large diversity of ecosystems in South Africa, further applied research would be beneficial to test optimal combinations of treatments, including alien control, spontaneous regeneration and active restoration methods for different ecosystems. In assessing the outcomes, the potential of recent technologies should be considered for use, especially for scaling up implementation. These include specialised seed coatings, mechanised sowing, and aerial imagery (remote sensing, high resolution aerial imagery and drones; Dufour et al. 2013; Zahawi et al. 2015; Rebelo et al. 2017; Harris et al. 2018). 
In South Africa, there has been limited implementation of ecological restoration results from published scientific papers, popular articles and guidelines, despite the need to scale up restoration interventions in the field. If we are to apply nature-based solutions to the urgent global challenges of invasive alien species, ecosystem degradation and climate change, ecological restoration efforts should be intensified. The limited action so far may relate to resource limitations, especially for active restoration interventions as these may be particularly resource-intensive. Funding streams for invasive plant management in South Africa currently focus on the removal of invasive alien plant stands, and a shift in mind-set is needed to incorporate restoration goals. For instance, spontaneous regeneration approaches that are less resource-intensive than active restoration can easily be applied at scale. An example is to plan and apply the optimal clearing methods and timing of interventions correctly to ensure invasive alien removal is successful without damaging native species or seed banks, thus promoting the probability of spontaneous regeneration and reducing long-term restoration costs.

It is important to promote stakeholder involvement in restoration projects as this is more likely to result in securing resources for larger-scale implementation. One example of this is the Blaauwberg Sand Fynbos project where researchers, conservation managers, volunteers and other organisations are involved. Ecological restoration is being implemented as and when resources are secured. Another example is the Berg River restoration project which involves government agencies, researchers, land-owners, restoration practitioners and other stakeholders who together plan and implement restoration interventions in the field.

Despite the above examples, South Africa has a long way to go to meet the required international targets, such as the Convention on Biological Diversity 2020 Aichi Target 14 (restore and protect ecosystems providing essential services) and Target 15 (restore $15 \%$ of degraded ecosystems to contribute to climate change mitigation and adaptation).

Acknowledgements Much of the work reviewed in this chapter was supported by the DSI-NRF Centre of Excellence for Invasion Biology and the Natural Resources Management programme of the Department Of Environmental Affairs as part of the collaborative research project on "Integrated management of invasive alien species in South Africa". Additional support was provided by the National Research Foundation (grant 85417).

\section{References}

Anderson SJ, Ankor BL, Sutton PC (2017) Ecosystem service valuations of South Africa using a variety of land cover data sources and resolutions. Ecosys Serv 27:173-178. https://doi.org/10. 1016/j.ecoser.2017.06.001

Aronson J, Milton SJ, Blignaut JN (2007) Restoring natural capital: definitions and rationale. In: Aronson J, Milton SJ, Blignaut JN (eds) Restoring natural capital; science, business and practice. Island Press, Washington DC, pp 3-8 
Aronson J, Blignaut JN, Aronson TB (2017) Conceptual frameworks and references for landscapescale restoration: reflecting back and looking forward. Ann Miss Bot Gard 102:188-200. https:// doi.org/10.3417/2017003

Balaguer L, Escudero A, Martín-Duque JF et al (2014) The historical reference in restoration ecology: re-defining a cornerstone concept. Biol Conserv 176:12-20. https://doi.org/10.1016/j. biocon.2014.05.007

Beater MMT, Garner RD, Witkowski ETF (2008) Impacts of clearing invasive alien plants from 1995 to 2005 on vegetation structure, invasion intensity and ground cover in a temperate to subtropical riparian ecosystem. S Afr J Bot 74:495-507. https://doi.org/10.1016/j.sajb.2008.01. 174

Beisner BE, Haydon DT, Cuddington K (2003) Alternative stable states in ecology. Front Ecol Environ 1:376-382. https://doi.org/10.1890/1540-9295(2003)001[0376:ASSIE]2.0.CO;2

Blanchard R, Holmes PM (2008) Riparian vegetation recovery after invasive alien tree clearance in the Fynbos Biome. S Afr J Bot 74:421-431. https://doi.org/10.1016/j.sajb.2008.01.178

Bond WJ, Slingsby P (1983) Seed dispersal by ants in shrublands of the Cape Province and its evolutionary implications. S Afr J Sci 79:231-233

Brooks ML, D'Antonio CM, Richardson DM et al (2004) Effects of invasive alien plants on fire regimes. Bioscience 54:677-688. https://doi.org/10.1641/0006-3568(2004)054[0677:EOIAPO] 2.0.CO;2

Brown NAC (1993) Promotion of fynbos seeds by plant-derived smoke. New Phytol 123:575-583. https://doi.org/10.1111/j.1469-8137.1993.tb03770.x

Carrick PJ, Krüger R (2007) Restoring degraded landscapes in lowland Namaqualand: lessons from the mining experience and from regional ecological dynamics. J Arid Environm 70:767-781. https://doi.org/10.1016/j.jaridenv.2006.08.006

Clewell A, Aronson J, Winterhalder K (2004) The SER international primer on ecological restoration. Ecol Restor 2:206-207

Colvin C, Riemann K, Brown C et al (2009) Ecological and environmental impacts of large-scale groundwater development in the Table Mountain Group (TMG) aquifer system. Report to Water Research Commission of South Africa 1327, p 170

Convention on Biological Diversity Aichi Targets (2010) Aichi biodiversity targets. https://www. cbd.int/sp/targets/. Accessed 10 Apr 2019

Costanza R, de Groot R, Braat L et al (2017) Twenty years of ecosystem services: how far have we come and how far do we still need to go? Ecosyst Serv 28:1-16. https://doi.org/10.1016/j. ecoser.2017.09.008

Crookes DJ, Blignaut JN, de Wit MP et al (2013) System dynamic modelling to assess economic viability and risk trade-offs for ecological restoration in South Africa. J Environ Manage 120:138-147. https://doi.org/10.1016/j.jenvman.2013.02.001

Crossman ND, Bernard F, Egoh B et al (2017) The role of ecological restoration and rehabilitation in production landscapes: an enhanced approach to sustainable development (Working paper for the UNCCD Global Land Outlook)

Currie B, Milton SJ, Steenkamp JC (2009) Cost-benefit analysis of alien vegetation clearing for water yield and tourism in a mountain catchment in the Western Cape of South Africa. Ecol Econ 68:2574-2579. https://doi.org/10.1016/j.ecolecon.2009.04.007

D'Antonio CM, Meyerson LA (2002) Exotic plant species as problems and solutions in ecological restoration: a synthesis. Restor Ecol 10:703-713. https://doi.org/10.1046/j.1526-100X.2002. 01051.x

D'Antonio CM, Vitousek PM (1992) Biological invasions by exotic grasses, the grass/fire cycle, and global change. Annu Rev Ecol Syst 23:63-87. https://doi.org/10.1146/annurev.es.23. 110192.000431

Davies KW, Boyd CS, Madsen MD et al (2018) Evaluating a seed technology for sagebrush restoration across an elevation gradient: support for bet hedging. Rangel Ecol Manag 71:19-24. https://doi.org/10.1016/j.rama.2017.07.006 
Dew LA, Rozen-Rechels D, Roux E et al (2017) Evaluating the efficacy of invasive plant control in response to ecological factors. S Afr J Bot 109:203-213. https://doi.org/10.1016/j.sajb.2016.12. 007

Downey PO, Richardson DM (2016) Alien plant invasions and native plant extinctions: a six-threshold framework. AoB Plants 8:plw047. https://doi.org/10.1093/aobpla/plw047

Dufour S, Bernez I, Betbeder J et al (2013) Monitoring restored riparian vegetation: how can recent developments in remote sensing sciences help? Knowl Manage Aquat Ecosyst 410:10. https:// doi.org/10.1051/kmae/2013068

Falk AD, Fulbright TE, Smith FS et al (2013) Does seeding a locally adapted native mixture inhibit ingress by exotic plants? Restor Ecol 21:474-480. https://doi.org/10.1111/j.1526-100X.2012. 00918.x

Forup ML, Memmott J (2005) The restoration of plant-pollinator interactions in Hay meadows. Restor Ecol 13:265-274. https://doi.org/10.1111/j.1526-100X.2005.00034.X

Fourie S (2008) Composition of the soil seed bank in alien-invaded grassy fynbos: potential for recovery after clearing. S Afr J Bot 74:445-453. https://doi.org/10.1016/j.sajb.2008.01.172

Funk JL, Cleland EE, Suding KN et al (2008) Restoration through reassembly: plant traits and invasion resistance. Trends Ecol Evol 23:695-703. https://doi.org/10.1016/j.tree.2008.07.013

Fynn RW, Wragg PD, Morris CD et al (2009) Vegetative traits predict grass species' invasiveness and the invasibility of restored grassland. Afr J Range For Sci 26:59-68. https://doi.org/10. 2989/AJRFS.2009.26.2.2.845

Gaertner M, Richardson DM, Privett SDJ (2011) Effects of alien plants on ecosystem structure and functioning and implications for restoration: insights from three degraded sites in South African fynbos. Environ Manage 48:57-69. https://doi.org/10.1007/s00267-011-9675-7

Gaertner M, Fisher J, Sharma G et al (2012a) Insights into invasion and restoration ecology: time to collaborate towards a holistic approach to tackle biological invasions. NeoBiota 12:57-76. https://doi.org/10.3897/neobiota.12.2123

Gaertner M, Holmes PM, Richardson DM (2012b) Biological invasions, resilience and restoration. In: van Andel J, Aronson J (eds) Restoration ecology: the new frontier, 2nd edn. Wiley Blackwell, Oxford, pp 265-280. https://doi.org/10.1002/9781118223130.ch20

Gaertner M, Nottebrock H, Fourie H et al (2012c) Plant invasions, restoration, and economics: perspectives from South African fynbos. Perspect Plant Ecol Evol Syst 14:341-353. https://doi. org/10.1016/j.ppees.2012.05.001

Gaertner M, Biggs R, Te Beest M et al (2014) Invasive plants as drivers of regime shifts: identifying high-priority invaders that alter feedback relationships. Divers Distrib 20:733-744. https://doi. org/10.1111/ddi.12182

Galatowitsch S, Richardson DM (2005) Riparian scrub recovery after clearing of invasive alien trees in headwater streams of the Western Cape, South Africa. Biol Conserv 122:509-521. https://doi.org/10.1016/j.biocon.2004.09.008

Galloway AD, Holmes PM, Gaertner M et al (2017) The impact of pine plantations on fynbos above-ground vegetation and soil seed bank composition. S Afr J Bot 113:300-307. https://doi. org/10.1016/j.sajb.2017.09.009

Geerts S, Pauw A (2009) African sunbirds hover to pollinate an invasive hummingbird-pollinated plant. Oikos 118:573-579. https://doi.org/10.1111/j.1600-0706.2008.17167.x

Geldenhuys CJ (2013) Converting invasive alien plant stands to natural forest nature's way. Overview, theory, and practice. In: Jose S, Singh HP, Batish DR et al (eds) Invasive plant ecology. CRC, Boca Raton, pp 217-237. https://doi.org/10.1201/b13865-17

Geldenhuys CJ, Atsame-Edda A, Mugure MW (2017) Facilitating the recovery of natural evergreen forests in South Africa via invader plant stands. Forest Ecosys 4:21. https://doi.org/10.1186/ s40663-017-0108-9

Hall SAW (2018) Restoration potential of alien-invaded Lowland Fynbos. PhD thesis. Stellenbosch University, Stellenbosch 
Hall SA, Newton RJ, Holmes PM et al (2017) Heat and smoke pre-treatment of seeds to improve restoration of an endangered Mediterranean climate vegetation type. Austral Ecol 42:354-366. https://doi.org/10.1111/aec.12449

Harris D, Vlok J, van Niekerk A (2018) Regional mapping of spekboom canopy cover using very high resolution aerial imagery. J Appl Remote Sens 12:046022. https://doi.org/10.1117/1.JRS. 12.046022

Herron CM, Jonas JL, Meiman PJ et al (2013) Using native annual plants to restore post-fire habitats in western North America. Int J Wildl Fire 22:815-821. https://doi.org/10.1071/ WF11179

Hill MP, Moran VC, Hoffmann JH et al (2020) More than a century of biological control against invasive alien plants in South Africa: a synoptic view of what has been accomplished. In: van Wilgen BW, Measey J, Richardson DM et al (eds) Biological invasions in South Africa. Springer, Berlin, pp 549-568. https://doi.org/10.1007/978-3-030-32394-3_19

Hitchcock A, Cowell C, Rebelo T (2012) The lost fynbos of Tokai Park. Veld Flora 98:30-33

Hobbs RJ, Richardson DM (2011) Invasion ecology and restoration ecology: parallel evolution in two fields of Endeavour. In: Richardson DM (ed) Fifty years of invasion ecology. The legacy of Charles Elton. Wiley-Blackwell, Oxford, pp 61-69. https://doi.org/10.1002/9781444329988. ch6

Hobbs RJ, Higgs E, Harris JA (2009) Novel ecosystems: implications for conservation and restoration. Trends Ecol Evol 24:599-605. https://doi.org/10.1016/j.tree.2009.05.012

Holl KD, Zahawi RA, Cole RJ et al (2011) Planting seedlings in tree islands versus plantations as a large-scale tropical forest restoration strategy. Restor Ecol 19:470-479. https://doi.org/10.1111/ j.1526-100X.2010.00674.x

Holmes PM (2001a) A comparison of the impacts of winter versus summer burning of slash fuel in alien-invaded fynbos areas in the Western Cape. South Afr For J 192:41-50. https://doi.org/10. 1080/20702620.2001.10434132

Holmes PM (2001b) Shrubland restoration following woody alien invasion and mining: effects of topsoil depth, seed source, and fertilizer addition. Restor Ecol 9:71-84. https://doi.org/10.1046/ j.1526-100x.2001.009001071.x

Holmes PM (2002) Depth distribution and composition of seed banks alien-invaded and uninvaded fynbos vegetation. Austral Ecol 27:110-120

Holmes PM, Cowling RM (1997) The effects of invasion by Acacia saligna on the guild structure and regeneration capabilities of South African fynbos shrublands. J Appl Ecol 34:317-332. https://doi.org/10.2307/2404879

Holmes PM, Marais C (2000) Impacts of alien plant clearance on vegetation in the mountain catchments of the Western Cape. South Afr For J 189:113-117. https://doi.org/10.1080/ 10295925.2000.9631286

Holmes PM, Richardson DM (1999) Protocols for restoration based on recruitment dynamics, community structure, and ecosystem function: perspectives from South African fynbos. Restor Ecol 7:215-230. https://doi.org/10.1046/j.1526-100X.1999.72015.x

Holmes PM, Richardson DM, van Wilgen BW et al (2000) Recovery of South African fynbos vegetation following alien woody plant clearing and fire: implications for restoration. Austral Ecol 25:631-639. https://doi.org/10.1111/j.1442-9993.2000.tb00069.x

Holmes PM, Richardson DM, Esler KJ et al (2005) A decision-making framework for restoring riparian zones degraded by invasive alien plants in South Africa. S Afr J Sci 101:553-564

Holmes PM, Richardson DM, Marais C (2007) Costs and benefits of restoring natural capital following alien plant invasions in the fynbos ecosystems in South Africa. In: Aronson J, Milton SJ, Blignaut JN (eds) Restoring natural capital; science, business and practice. Island Press, Washington DC, pp 188-197

James JJ, Carrick PJ (2016) Toward quantitative dryland restoration models. Restor Ecol 24:85-90. https://doi.org/10.1111/rec.12393

Kaiser-Bunbury CN, Mougal J, Whittington AE et al (2017) Ecosystem restoration strengthens pollination network resilience and function. Nature 542:223-227. https://doi.org/10.1038/ nature 21071 
Kerr TF, Ruwanza S (2016) Does Eucalyptus grandis invasion and removal affect soils and vegetation in the Eastern Cape Province, South Africa? Austral Ecol 41:328-338. https://doi. org/10.1111/aec. 12315

Kettenring KM, Adams CR (2011) Lessons learned from invasive plant control experiments : a systematic review and meta-analysis. J Appl Ecol 48:970-979. https://doi.org/10.1111/j.13652664.2011.01979.x

Kimball S, Lulow M, Sorenson Q et al (2015) Cost-effective ecological restoration. Restor Ecol 23:800-810. https://doi.org/10.1111/rec.12261

Kraaij T, van Wilgen BW (2014) Drivers, ecology, and management of fire in fynbos. In: Allsopp N, Colville JF, Verboom AG (eds) Fynbos: ecology, evolution, and conservation of a megadiverse region. Oxford University Press, Oxford, pp 47-72. https:/doi.org/10.1093/ acprof:oso/9780199679584.003.0003

Krupek A, Gaertner M, Holmes PM et al (2016) Assessment of post-burn removal methods for Acacia saligna in Cape Flats Sand Fynbos, with consideration of indigenous plant recovery. S Afr J Bot 105:211-217. https://doi.org/10.1016/j.sajb.2016.04.004

Kull CA, Shackleton CM, Cunningham PJ et al (2011) Adoption, use, and perception of Australian acacias around the world. Divers Distrib 17:822-836. https://doi.org/10.1111/j.1472-4642. 2011.00783.x

Laughlin DC (2014) Applying trait-based models to achieve functional targets for theory-driven ecological restoration. Ecol Lett 17:771-784. https://doi.org/10.1111/ele.12288

Le Maitre DC, Gaertner M, Marchante E et al (2011) Impacts of invasive Australian acacias: implications for management and restoration. Divers Distrib 17:1015-1029. https://doi.org/10. 1111/j.1472-4642.2011.00816.x

Macdonald IAW (1984) Is the fynbos biome especially susceptible to invasion by alien plants? A re-analysis of available data. S Afr J Sci 80:369-377

Macdonald IAW, Kruger FJ, Ferrar AA (eds) (1986) The ecology and management of biological invasions in southern Africa. Oxford University Press, Cape Town

Madsen MD, Davies KW, Boyd CS et al (2016) Emerging seed enhancement technologies for overcoming barriers to restoration. Restor Ecol 24:S77-S84. https://doi.org/10.1111/rec.12332

Magoba RN, Samways MJ (2010) Recovery of benthic macroinvertebrate and adult dragonfly assemblages in response to large scale removal of riparian invasive alien trees. $\mathrm{J}$ Insect Conserv 14:627-636. https://doi.org/10.1007/s10841-010-9291-5

Mangachena JR, Geerts S (2017) Invasive alien trees reduce bird species richness and abundance of mutualistic frugivores and nectarivores; a bird's eye view on a conflict of interest species in riparian habitats. Ecol Res 32:1-10. https://doi.org/10.1007/s11284-017-1481-0

Maoela MA, Jacobs SM, Roets F (2016) Invasion, alien control and restoration: legacy effects linked to folivorous insects and phylopathogenic fungi. Austral Ecol 41:906-917. https://doi. org/10.1111/aec. 12383

Marais C, Wannenburgh AM (2008) Restoration of water resources (natural capital) through the clearing of invasive alien plants from riparian areas in South Africa - costs and water benefits. S Afr J Bot 74:526-537. https://doi.org/10.1016/j.sajb.2008.01.175

Marais KE, Pratt RB, Jacobs SM et al (2014) Postfire regeneration of resprouting mountain fynbos shrubs: differentiating obligate resprouters and facultative seeders. Plant Ecol 215:195-208. https://doi.org/10.1007/s11258-013-0289-4

Marchante E, Kjøller A, Struwe S et al (2009) Soil recovery after removal of the N2-fixing invasive Acacia longifolia: consequences for ecosystem restoration. Biol Invasions 11:813-823. https:// doi.org/10.1007/s10530-008-9295-1

Martin A, Khater C, Mineau H et al (2002) Rehabilitation ecology by revegetation. Approach and results from two Mediterranean countries. Korean. J Ecol 25:9-17. https://doi.org/10.5141/ JEFB.2002.25.1.009

Matzek V, Warren S, Fisher C (2016) Incomplete recovery of ecosystem processes after two decades of riparian forest restoration. Restor Ecol 24:637-645. https://doi.org/10.1111/rec. 12361 
McConnachie MM, Cowling RM, van Wilgen BW et al (2012) Evaluating the cost-effectiveness of invasive alien plant clearing: a case study from South Africa. Biol Conserv 155:128-135. https://doi.org/10.1016/j.biocon.2012.06.006

McDonald T, Gann GD, Jonson J et al (2016a) International standards for the practice of ecological restoration - including principles and key concepts. Retrieved from http://c.ymcdn.com/sites/ www.ser.org/resource/resmgr/docs/SER_International_Standards.pdf

Mcdonald T, Jonson J, Dixon KW (2016b) National standards for the practice of ecological restoration in Australia. Restor Ecol 24:s4-s32. https://doi.org/10.1111/rec.12359

Meek CS, Richardson DM, Mucina L (2013) Plant communities along the Eerste River, Western Cape, South Africa: community descriptions and implications for restoration. Koedoe 55:1-14. https://doi.org/10.4102/koedoe.v55i1.1099

Metzger JP, Esler K, Krug C et al (2017) Best practice for the use of scenarios for restoration planning. Curr Opin Environ Sustain 29:14-25. https://doi.org/10.1016/j.cosust.2017.10.004

Mgobozi MP, Somers MJ, Dippenaar-Schoeman AS (2008) Spider responses to alien plant invasion: the effect of short- and long-term Chromolaena odorata invasion and management. J Appl Ecol 45:1189-1197. https://doi.org/10.1111/j.1365-2664.2008.01486.x

Milton SJ, Siegfried WR (1994) A conceptual model of arid rangeland degradation. Bioscience 44:70-76. https://doi.org/10.2307/1312204

Milton SJ, Dean WRJ, Richardson DM (2003) Economic incentives for restoring natural capital in southern African rangelands. Front Ecol Environ 1:247-254. https://doi.org/10.1890/1540-9295 (2003)001[0247:EIFRNC]2.0.CO;2

Modiba RV, Joseph GS, Seymour CL et al (2017) Restoration of riparian systems through clearing of invasive plant species improves functional diversity of Odonate assemblages. Biol Conserv 214:46-54. https://doi.org/10.1016/j.biocon.2017.07.031

Mohieldin M, Caballero P (2015) Protect, restore and promote sustainable use of terrestrial ecosystems, sustainably manage forests, combat desertification, and halt and reverse land degradation and halt biodiversity loss. UN Chron 51(4):34-35. https://doi.org/10.18356/ f405cab8-en

Moran VC, Hoffmann JH (2012) Conservation of the fynbos biome in the Cape Floral Region: the role of biological control in the management of invasive alien trees. BioControl 57:139-149. https://doi.org/10.1007/s10526-011-9403-5

Morgan JW (1999) Have tubestock plantings successfully established populations of rare grassland species into reintroduction sites in western Victoria? Biol Conserv 89:235-243. https://doi.org/ 10.1016/S0006-3207(99)00014-2

Mori AS, Furukawa T, Sasaki T (2013) Response diversity determines the resilience of ecosystems to environmental change. Biol Rev 88:349-364. https://doi.org/10.1111/brv.12004

Morris TL, Witkowski ETF, Coetzee JA (2008) Initial response of riparian plant community structure to clearing of invasive alien plants in Kruger National Park, South Africa. S Afr J Bot 74:485-494. https://doi.org/10.1016/j.sajb.2008.01.177

Mostert E, Gaertner M, Holmes PM et al (2017) Impacts of invasive alien trees on threatened lowland vegetation types in the Cape Floristic Region, South Africa. S Afr J Bot 108:209-222. https://doi.org/10.1016/j.sajb.2016.10.014

Mostert E, Gaertner M, Holmes PM et al (2018) A multi-criterion approach for prioritizing areas in urban ecosystems for active restoration following invasive plant control. Environ Manag 62:1150-1167. https://doi.org/10.1007/s00267-018-1103-9

Mugwedi LF, Rouget M, Egoh B et al (2017) An assessment of a community-based, forest restoration programme in Durban (eThekwini), South Africa. Forests 8:255. https://doi.org/ $10.3390 / 88080255$

Mugwedi LF, Ray-Mukherjee J, Roy KE et al (2018) Restoration planning for climate change mitigation and adaptation in the city of Durban, South Africa. Int J Biodivers Sci Ecosyst Serv Manage 14:132-144. https://doi.org/10.1080/21513732.2018.1483967

Ndou E, Ruwanza S (2016) Soil and vegetation recovery following alien tree clearing in the Eastern Cape Province of South Africa. Afr J Ecol 54:460-470. https://doi.org/10.1111/aje.12305 
Norton DA (2009) Species invasions and the limits to restoration: learning from the New Zealand experience. Science 325:569-571. https://doi.org/10.1126/science.1172978

Nsikani MM, Novoa A, van Wilgen BW et al (2017) Acacia saligna 's soil legacy effects persist up to 10 years after clearing: implications for ecological restoration. Austral Ecol 42:880-889. https://doi.org/10.1111/aec.12515

Nsikani MM, van Wilgen BW, Gaertner M (2018) Barriers to ecosystem restoration presented by soil legacy effects of invasive alien N2-fixing woody species: implications for ecological restoration. Restor Ecol 26:235-244. https://doi.org/10.1111/rec.12669

Ntshotsho P, Reyers B, Esler KJ (2011) Assessing the evidence base for restoration in South Africa. Restor Ecol 19:578-586. https://doi.org/10.1111/j.1526-100X.2010.00753.x

Pearson DE, Ortega YK, Runyon JB et al (2016) Secondary invasion: the bane of weed management. Biol Conserv 197:8-17. https://doi.org/10.1016/j.biocon.2016.02.029

Pretorius MR, Esler KJ, Holmes PM et al (2008) The effectiveness of active restoration following alien clearance in fynbos riparian zones and resilience of treatments to fire. S Afr J Bot 74:517-525. https://doi.org/10.1016/j.sajb.2008.01.180

Prins N, Holmes PM, Richardson DM (2004) A reference framework for the restoration of riparian vegetation in the Western Cape, South Africa, degraded by invasive Australian Acacias. S Afr J Bot 70:767-776. https://doi.org/10.1016/S0254-6299(15)30178-2

Raimondo D, Staden VL, Foden W (2009) Red list of South African Plants. South African National Biodiversity Institute, Pretoria

Rebelo AJ, Scheunders P, Esler KJ et al (2017) Detecting, mapping and classifying wetland fragments at a landscape scale. Remote Sensing Appl Soc Environ 8:212-223. https://doi.org/ 10.1016/j.rsase.2017.09.005

Reyers B, O'Farrell PJ, Cowling RM et al (2009) Ecosystem services, land-cover change, and stakeholders: finding a sustainable foothold for a semiarid biodiversity hotspot. Ecol Soc 14:38. https://doi.org/10.5751/ES-02867-140138

Richardson DM, van Wilgen BW (2004) Invasive alien plants in South Africa: how well do we understand the ecological impacts. S Afr J Sci 100:45-52

Richardson DM, Macdonald IAW, Hoffmann JH et al (1997) Alien plant invasions. In: Cowling RM, Richardson DM, Pierce SM (eds) Vegetation of Southern Africa. Cambridge University Press, Cambridge, pp 535-570

Richardson DM, Bond WJ, Dean WRJ et al (2000) Invasive alien organisms and global change: a South African perspective. In: Mooney HA, Hobbs RJ (eds) Invasive species in a changing world. Island Press, Washington DC, pp 303-349

Richardson DM, Holmes PM, Esler KJ et al (2007) Riparian vegetation: degradation, alien plant invasions, and restoration prospects. Divers Distrib 13:126-139. https://doi.org/10.1111/j.13669516.2006.00314.x

Rohr JR, Johnson P, Hickey CW et al (2013) Implications of global climate change for natural resource damage assessment, restoration, and rehabilitation. Environ Toxicol Chem 32:93-101. https://doi.org/10.1002/etc.2036

Rohr JR, Bernhardt ES, Cadotte MW et al (2018) The ecology and economics of restoration : when, what, where, and how to restore ecosystems. Ecol Soc 23:15. https://doi.org/10.5751/ES-09876230215

Rouwntree K (1991) An assessment of the potential impact of alien invasive vegetation on the geomorphology of river channels in South Africa. South Afr J Aquat Sci 17:28-43. https://doi. org/10.1080/10183469.1991.9631311

Ruwanza S, Gaertner M, Esler KJ et al (2013a) Both complete clearing and thinning of invasive trees lead to short-term recovery of native riparian vegetation in the Western Cape, South Africa. Appl Veg Sci 16:193-204. https://doi.org/10.1111/j.1654-109X.2012.01222.x

Ruwanza S, Gaertner M, Richardson DM et al (2013b) Soil water repellency in riparian systems invaded by Eucalyptus camaldulensis: a restoration perspective from the Western Cape Province, South Africa. Geoderma 200-201:9-17. https://doi.org/10.1016/j.geoderma.2013.01.017 
Ruwanza S, Gaertner M, Esler KJ et al (2015) Allelopathic effects of invasive Eucalyptus camaldulensis on germination and early growth of four native species in the Western Cape, South Africa. South For 77:91-105. https://doi.org/10.2989/20702620.2014.965985

Ruwanza S, Gaertner M, Esler KJ et al (2018) Medium-term vegetation recovery after removal of invasive Eucalyptus camaldulensis stands along a South African river. S Afr J Bot 119:63-68. https://doi.org/10.1016/j.sajb.2018.08.002

Samways MJ, Sharratt NJ, Simaika JP (2011) Effect of alien riparian vegetation and its removal on a highly endemic river macroinvertebrate community. Biol Invasions 13:1305-1324. https://doi. org/10.1007/s10530-010-9891-8

Sher AA, Hyatt LA (1999) The disturbed resource-Flux Invasion Matrix: a new framework for patterns of plant invasion. Biol Invasions 1:107-114. https://doi.org/10.1023/ A:1010050420466

Stafford W, Blignaut J (2017) Reducing landscape restoration costs: feasibility of generating electricity from invasive alien plant biomass on the Agulhas Plain, South Africa. Ecosys Serv 27:224-231. https://doi.org/10.1016/j.ecoser.2017.04.008

Stafford W, Birch C, Etter H et al (2017) The economics of landscape restoration: benefits of controlling bush encroachment and invasive plant species in South Africa and Namibia. Ecosyst Serv 27:193-202. https://doi.org/10.1016/j.ecoser.2016.11.021

Standish RJ, Cramer VA, Wild SL et al (2007) Seed dispersal and recruitment limitation are barriers to native recolonization of old-fields in western Australia. J Appl Ecol 44:435-445. https://doi. org/10.1111/j.1365-2664.2006.01262.x

Stanturf JA, Palik BJ, Williams MI et al (2014) Forest restoration paradigms. J Sustain For 33 (Sup1):S161-S194. https://doi.org/10.1080/10549811.2014.884004

Strydom M, Esler KJ, Wood AR (2012) Acacia saligna seed banks: sampling methods and dynamics, Western Cape, South Africa. S Afr J Bot 79:140-147. https://doi.org/10.1016/j. sajb.2011.10.007

Strydom M, Veldtman R, Ngwenya MZ et al (2017) Invasive Australian Acacia seed banks: size and relationship with stem diameter in the presence of gall-forming biological control agents. PLoS One 12:e0181763. https://doi.org/10.1371/journal.pone.0181763

Suding KN, Hobbs RJ (2009) Threshold models in restoration and conservation: a developing framework. Trends Ecol Evol 24:271-279. https://doi.org/10.1016/j.tree.2008.11.012

Suding K, Leger E (2012) Shifting baselines: dynamics of evolution and community change in a changing world. In: van Andel J, Aronson J (eds) Restoration ecology: the new frontier, 2nd edn. Wiley Blackwell, Oxford, pp 282-292. https://doi.org/10.1002/9781118223130.ch21

Suding KN, Gross KL, Houseman GR (2004) Alternative states and positive feedbacks in restoration ecology. Trends Ecol Evol 19:46-53. https://doi.org/10.1016/j.tree.2003.10.005

Suding K, Higgs E, Palmer M et al (2015) Committing to ecological restoration. Science 348:638-640. https://doi.org/10.1126/science.aaa4216

Temperton VM, Higgs E, Choi YD et al (2014) Flexible and adaptable restoration: an example from South Korea. Restor Ecol 22:271-278. https://doi.org/10.1111/rec.12095

Tererai F, Gaertner M, Jacobs SM et al (2013) Eucalyptus invasions in riparian forests: effects on native vegetation community diversity, stand structure and composition. For Ecol Manag 297:84-93. https://doi.org/10.1016/j.foreco.2013.02.016

Tererai F, Gaertner M, Jacobs SM et al (2015a) Eucalyptus camaldulensis invasion in riparian zones reveals few significant effects on soil physico-chemical properties. River Res Appl 31:590-601. https://doi.org/10.1002/rra.2762

Tererai F, Gaertner M, Jacobs SM et al (2015b) Resilience of invaded riparian landscapes: the potential role of soil-stored seed banks. Environ Manage 55:86-99. https://doi.org/10.1007/ s00267-014-0374-z

Török K, Szili-Kovács T, Halassy M et al (2000) Immobilization of soil nitrogen as a possible method for the restoration of sandy grassland. Appl Veg Sci 3:7-14. https://doi.org/10.2307/ 1478913 
Traveset A, Richardson DM (2006) Biological invasions as disruptors of plant reproductive mutualisms. Trends Ecol Evol 21:208-216. https://doi.org/10.1016/j.tree.2006.01.006

Turner SR, Pearce B, Rokich DP et al (2006) Influence of polymer seed coatings, soil raking, and time of sowing on seedling performance in post-mining restoration. Restor Ecol 14:267-277. https://doi.org/10.1111/j.1526-100X.2006.00129.x

Turner KG, Grace K, Anderson S et al (2016) A review of methods, data, and models to assess changes in the value of ecosystem services from land degradation and restoration a review of methods, data, and models to assess changes in the value of ecosystem services from land degradation and resto. Ecol Model 319:190-207. https://doi.org/10.1016/j.ecolmodel.2015.07. 017

Turpie JK, Marais C, Blignaut JN (2008) The working for water programme: evolution of a payments for ecosystem services mechanism that addresses both poverty and ecosystem service delivery in South Africa. Ecol Econ 65:788-798. https://doi.org/10.1016/j.ecolecon.2007.12. 024

Urgenson LS, Prozesky HE, Esler KJ (2013) Stakeholder perceptions of an ecosystem services approach to clearing invasive alien plants on private land. Ecol Soc 18:26. https://doi.org/10. 5751/ES-05259-180126

van Wilgen BW (2018) The management of invasive alien plants in South Africa: strategy, progress and challenges. Outl Pest Manage 29(1):13-17. https://doi.org/10.1564/v29_feb_04

van Wilgen BW, Richardson DM, Seydack AHW (1994) Managing fynbos for biodiversity: constraints and options in a fire-prone environment. S Afr J Sci 90:322-329

van Wilgen BW, Carruthers J, Cowling RM et al (2016) Ecological research and conservation management in the Cape Floristic Region between 1945 and 2015: history, current understanding and future challenges ecological research and conservation management in the Cape Floristic Region between 1945 and 2015. Trans R Soc S Afr 71:207-303. https://doi.org/10. 1080/0035919X.2016.1225607

Vilà M, Espinar JL, Hejda M, Hulme PE, Jarošik V, Maron JL, Pergl J, Schaffner U, Yan Sun Y, Pyšek P (2011) Ecological impacts of invasive alien plants: a meta-analysis of their effects on species, communities and ecosystems. Ecol Lett 14:702-208. https://doi.org/10.1111/j.14610248.2011.01628.x

Vosse S, Esler KJ, Richardson DM et al (2008) Can riparian seed banks initiate restoration after alien plant invasion? Evidence from the Western Cape, South Africa. S Afr J Bot 74:432-444. https://doi.org/10.1016/j.sajb.2008.01.170

Waller PA, Anderson PM, Holmes PM et al (2016) Seedling recruitment responses to interventions in seed-based ecological restoration of Peninsula Shale Renosterveld, Cape Town. S Afr J Bot 103:193-209. https://doi.org/10.1016/j.sajb.2015.09.009

Walters C, Berjak P (2013) Preservation of recalcitrant seeds. Science 339:915-916. https://doi.org/ $10.1126 /$ science. 1230935

Whisenant SG (1999) Repairing damaged wildlands. Cambridge University Press, Cambridge. https://doi.org/10.1017/CBO9780511612565

Whisenant SG (2002) Terrestrial systems. In: Perrow MR, Davy AJ (eds) Handbook of ecological restoration, Principles of restoration, vol 1. Cambridge University Press, Cambridge, pp 83-105. https://doi.org/10.1017/CBO9780511549984.008

Wilson JR, Gaertner M, Griffiths CL et al (2014) Biological invasions in the Cape Floristic Region : history, current patterns, impacts, and management challenges. In: Allsopp N, Colville JF, Verboom GA (eds) Fynbos: ecology, evolution, and conservation of a megadiverse region. Oxford University Press, Oxford, pp 273-298. https://doi.org/10.1093/acprof:oso/ 9780199679584.003 .0012

Wood AR (2017) Fungi and invasions in South Africa. Bothalia 47:a2124. https://doi.org/10.4102/ abc.v47i2.2124

Yelenik SG, Stock WD, Richardson DM (2004) Ecosystem level impacts of invasive Acacia saligna in the South African fynbos. Restor Ecol 12:44-51. https://doi.org/10.1111/j.10612971.2004.00289.x 
Zahawi RA, Dandois JP, Holl KD et al (2015) Using lightweight unmanned aerial vehicles to monitor tropical forest recovery. Biol Conserv 186:287-295. https://doi.org/10.1016/j.biocon. 2015.03.031

Zaloumis NP, Bond WJ (2011) Grassland restoration after afforestation: no direction home? Austral Ecol 36:357-366. https://doi.org/10.1111/j.1442-9993.2010.02158.x

Zink TA, Allen MF (1998) The effects of organic amendments on the restoration of a disturbed coastal sage scrub habitat. Restor Ecol 6:52-58. https://doi.org/10.1046/j.1526-100x.1998. 00617.x

Open Access This chapter is licensed under the terms of the Creative Commons Attribution 4.0 International License (http://creativecommons.org/licenses/by/4.0/), which permits use, sharing, adaptation, distribution and reproduction in any medium or format, as long as you give appropriate credit to the original author(s) and the source, provide a link to the Creative Commons licence and indicate if changes were made.

The images or other third party material in this chapter are included in the chapter's Creative Commons licence, unless indicated otherwise in a credit line to the material. If material is not included in the chapter's Creative Commons licence and your intended use is not permitted by statutory regulation or exceeds the permitted use, you will need to obtain permission directly from the copyright holder. 